\title{
GOVERNING BAD BEHAVIOR BY USERS OF Multi-Sided Platforms
}

\author{
David S. Evans"
}

\begin{abstract}
Multi-sided platforms such as exchanges, search engines, social networks, and software platforms create value by assembling and serving communities of people and businesses. They generally solve a transaction problem that prevents agents from coming together to exchange value. An essential feature of these platforms is that they promote positive externalities between members of the community. But as with any community, there are numerous opportunities for people and businesses to create negative externalities, or engage in other bad behavior, that can reduce economic efficiency and, in the extreme, lead to the tragedy of the commons. Multi-sided platforms, acting selfishly to maximize their own profits, often develop governance mechanisms to reduce harmful behavior. They also develop rules to manage many of the same kinds of problems that beset communities subject to public laws and regulations. They enforce these rules through the exercise of property rights and, most importantly, through the "Bouncer's Right" to exclude agents from some quantum of the platform, including prohibiting some agents from the platform entirely. Private control is likely to be more efficient than social control (through laws and regulation) in dealing with negative externalities on platform communities because the platform owner can monitor bad behavior more closely and deal with this behavior more expeditiously than a public regulator. Therefore, the courts and antitrust authorities should exercise caution in finding anti-competitive exclusion when that exclusion is conducted as part of a private governance mechanism for dealing with bad behavior of some platform users that harm other users.
\end{abstract}

(C) 2012 David S. Evans.

† Chairman, Global Economics Group; Lecturer, University of Chicago Law School; Visiting Professor, Faculty of Laws, University College London. I would like to thank Richard Epstein and Richard Schmalensee for helpful comments; Lauren Chiang, Jacqueline Murphy, Steven Joyce, Margaret Schilt, and Nikhil Tuladhar for excellent research help; and Google for research funding. None of these individuals or entities necessarily agrees with me and I retain sole ownership of any errors. 


\section{TABLE OF CONTENTS}

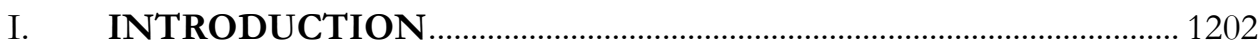

II. MULTI-SIDED PLATFORM STRATEGIES FOR

INCREASING VALUE ......................................................................... 1207

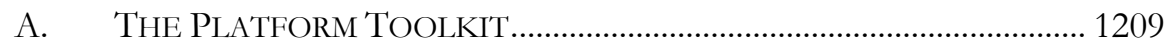

B. VALUE CREATION AND EXTERNALITIES........................................... 1210

C. VALUE Distribution AND COORDINATION..................................... 1211

III. BAD BEHAVIOR AND PLATFORM COMMUNITIES................... 1212

A. IT OUGHT TO BE A CRIME ……………………................................. 1214

B. POOR AND ASYMMETRIC INFORMATION.......................................... 1215

C. CONGESTION AND OPTIMIZING PHYSICAL SPACES.......................... 1216

D. CASE IN POINT: DECORMYEYES …………………………………..... 1216

E. BAD BEHAVIOR AND PLATFORM VALUE.............................................. 1218

IV. DEALING WITH BAD BEHAVIOR …….............................................. 1218

A. THE PROPERTY RIgHTS FRAMEWORK ………..................................... 1220

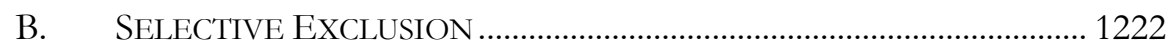

C. INFORMATION AND TRANSPARENCY.................................................. 1225

V. GOVERNANCE REGIMES FOR KEY PLATFORMS ..................... 1226

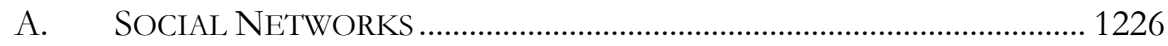

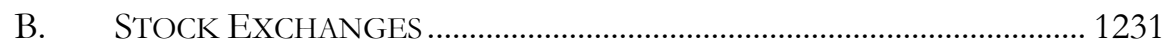

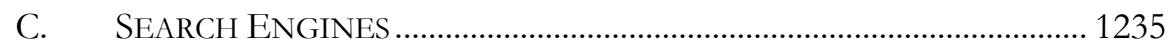

VI. PRIVATE VS. PUBLIC GOVERNANCE IN THE REGULATION OF BAD BEHAVIOR ON PLATFORMS ............... 1240

A. The Benefits of Private Regulation …………………………... 1241

B. ANTI-COMPETITIVE EXCLUSION: A PROPOSED THREe-STEP

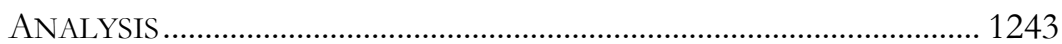

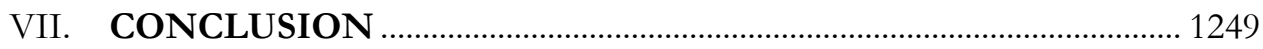

\section{INTRODUCTION}

If you win an auction on eBay but do not get the good, or the good is not what was advertised, you can complain to the e-commerce site in addition to giving the merchant a low rating. The site may decide to punish the merchant, including prohibiting them from ever selling again on eBay. Merchants receive protections too. Consumers are required to pay for any item they win in an auction and can bid only if they intend to buy the item that they win. Among other things, these rules prohibit consumers from 
bidding in several auctions for similar items and then only paying for the cheapest item they have won. ${ }^{1}$ Consumers that have too many unpaid items can lose their buying privileges. ${ }^{2}$ eBay has a system that governs bad behavior by the consumers and merchants that use its website. Many other businesses that are multi-sided platforms, like eBay, also have governance systems for dealing with bad behavior that creates negative externalities ${ }^{3}$ across platform participants. This Article examines these governance systems and explores the relationship between the public and private control of negative externalities.

Multi-sided platforms create value by helping two or more different types of users, who could benefit from getting together, find and interact with each other, and exchange value. ${ }^{4}$ They include software platforms (e.g., Apple's iOS), financial exchanges (e.g., NASDAQ), search engines (e.g., Microsoft's Bing), social networks (e.g., LinkedIn), shopping malls (e.g., Water Tower Place in Chicago), advertising-supported media (e.g., CNN), and e-commerce sites that connect businesses and shoppers (e.g., Amazon). ${ }^{5}$ Multi-sided platforms solve a transaction problem ${ }^{6}$ that prevents these different types of users from getting together on their own to exchange value. There are positive externalities between the multiple types of users. Platforms provide

1. For guidance relating to the rules for buyers and sellers on eBay, see Rules \& Policies, EBAY, http://pages.ebay.com/help/policies/overview.html (last visited Aug. 1, 2011).

2. For eBay's policies on unpaid items see Unpaid Item Policy, EBAY, http://pages.ebay.com/help/policies/unpaid-item.html (last visited Apr. 18, 2012).

3. Externalities are costs and benefits that agents impose on each other and are not transmitted through the price system. Generally, externalities involve a lack of direct agreement between the agents to bear the cost or provide the benefit and a lack of direct compensation for bearing costs or providing benefits. Negative externalities, such as air pollution and barking dogs, involve costs. Positive externalities, such as restoring historical buildings, researching new technologies, and pursuing education, involve benefits. See N. Greg MANKIW, Principles of ECONOMics 204-07 (3d ed. 2004).

4. See Bernard Caillaud \& Bruno Jullien, Chicken and Egg: Competition Among Intermediation Service Providers, 34 RAND J. OF ECON. 309, 309-310 (2003); Jean-Charles Rochet \& Jean Tirole, Platform Competition in Two-Sided Markets, $1 \mathrm{~J}$. OF THE Eur. ECON. Ass'N 990, 990 (2003).

5. See generally David S. Evans, Some Empirical Aspects of Multi-sided Platform Industries, 2 Rev. of Network ECON. 191 (2003); DAvid S. Evans \& Richard Schmalensee, Catalyst Code: The Strategies Behind the World's Most Dynamic Companies (2007); Thomas Eisenmann, Geoffrey Parker \& Marshall W. Van Alstyne, Strategies for TwoSided Markets, 84 HARV. Bus. REV. 92 (2006).

6. As Rochet \& Tirole observe, the inapplicability of the Coase Theorem is a necessary condition for the existence of a multi-sided platform. Jean-Charles Rochet \& Jean Tirole, Two-Sided Markets: A Progress Report, 37 RAND J. ECON 645, 649 (2006). When the Coase Theorem holds, individual users would be able to engage in value-maximizing exchange directly. See Ronald Coase, The Problem of Social Cost, 3 J. OF L. \& ECON. 1 (1960). 
ways to promote these positive externalities and thereby create value for the community of users they serve. ${ }^{7}$

Whenever people and businesses get together, and in any community, there are many opportunities for people and businesses to behave badly and to thereby generate negative externalities. This bad behavior can reduce economic efficiency and in the extreme lead to the tragedy of the commons. ${ }^{8}$ Multi-sided platforms such as eBay develop governance systems to reduce this bad behavior and minimize negative externalities. This Article shows that multi-sided platforms develop systems of rules and penalties to manage many of the same kinds of problems that communities subject to public laws and regulations face. These platforms enforce such rules by exercising their property rights to exclude users from the platform. In some cases, the rules and penalties imposed by the platform are similar to, and in some cases close substitutes for, rules and penalties adopted by a public regulator.

Private control is likely to be more efficient than social control ${ }^{9}$ in dealing with negative externalities in platform communities. The platform owner can monitor bad behavior more closely and deal with this behavior more quickly than can a public regulator. Multi-sided platforms face antitrust complaints concerning reductions in service or denial of service by the platform. This Article argues that the courts and antitrust authorities should exercise caution in assessing these claims when the exclusion at issue is related to platform governance for dealing with bad behavior. It proposes a three-step test for anti-competitive exclusion in these cases in which the burden shifts to the complainant when the platform has engaged in exclusion as part of an established internal governance system.

Despite the pervasiveness of private governance systems for bad behavior, there is little research on the topic and none that examines the public policy issues addressed in this paper. Rochet and Tirole were the first to identify the role of the platform as a regulator in their seminal paper on two-sided platforms. ${ }^{10}$ Boudreau and Hagiu present a detailed analysis of platform regulation and highlight the fact that platforms leverage a wide variety, and nuanced set, of instruments to maximize value. ${ }^{11}$ However, they treat all non-price instruments used by platforms as a form of regulation for

7. See David S. Evans \& Richard Schmalensee, The Industrial Organization of Markets with Two-Sided Platforms, 3 COMPETITION POL'Y INT’L 151, 154 (2007).

8. See generally Garrett Hardin, The Tragedy of the Commons, 162 SCIENCE 1243 (1968).

9. "Social control" refers to the enforcement of public laws and regulations.

10. Rochet \& Tirole, supra note 4. See also Evans \& Schmalensee, supra note 7, at 163.

11. See Kevin J. Boudreau \& Andrei Hagiu, Platforms Rules: Multi-Sided Platforms as Regulators, in PLATFORMS, MARKETS, AND INNOVATION 163 (Annabelle Gawer ed., 2009). 
market failures and consider a multitude of strategies for addressing positive and negative externalities. This Article focuses narrowly on the existence of negative externalities among platform users and the use of governance systems to deal with this bad behavior. It shows that these practices are analogous to the governance systems for communities, clubs, and other similar entities.

The analysis here is loosely related to the framework put forward by Strahilevitz. ${ }^{12} \mathrm{He}$ argues that property rights include several subordinate rights that enable private businesses to deal with information asymmetries and examines the extent to which private property rights and public governance systems are substitutes. This Article adopts his framework of subordinate property rights but then examines how these rights facilitate the development of private governance systems for multi-sided platforms that, like polities, must govern a community of members who may interact positively or negatively with each other.

The governance of bad behavior among members of platform communities is a worthy subject for several reasons.

First, although multi-sided platforms have existed for thousands of years, they are becoming an increasingly important part of the fabric of the economy. The development of the Internet has facilitated the creation of these platforms and some of these platforms have become global businesses quite rapidly. For example, Facebook, which started in 2004, has more than 845 million active monthly users worldwide, ${ }^{13}$ integrates more than 7 million applications and websites, ${ }^{14}$ and had advertising revenue in 2011 of more than $\$ 3.1$ billion. ${ }^{15}$ Understanding key aspects of how these platforms work helps in numerous contexts ranging from business to litigation.

Second, as shown below, many of these platforms have developed private governance regimes. These private systems include rules, standards, detection, penalties, adjudication, and other elements. They apply to significant portions of the world's population as a result of the global growth of these platforms. For example, most businesses have websites that are indexed by Google and many people have Facebook pages. Both of these platforms have private governance systems that among other things can expel users from the platform for violations.

12. Lior Strahilevitz, Information Asymmetries and the Rights to Exclude, $104 \mathrm{MICH}$. L. REV. 1835, 1838 (2006).

13. Facebook, Inc., Registration Statement (Form S-1), at 1 (Feb. 1, 2012), available at http://sec.gov/Archives/edgar/data/1326801/000119312512034517/d287954ds1.htm.

14. Id. at 75 .

15. Id. at 50 . 
Third, the ability of platforms to enforce rules concerning negative externalities rests on being able to penalize and ultimately exclude members of the community. That naturally leads to disputes that sometimes end up before courts or regulatory authorities. These issues arise particularly when penalties are levied against platform users that provide services that compete, or might compete, with those provided by the platform. Many of the current antitrust complaints against Google, for example, involve companies that protest that their businesses have been harmed as a result of reductions in their search ranking and that Google gives preferential treatment to its own vertical search or price-compensation services. ${ }^{16}$ Understanding the role of rules in policing negative externalities can help distinguish pro-competitive from anti-competitive business practices of platform owners.

After providing a brief introduction to multi-sided platforms, Part II situates the governance of negative externalities in the larger set of practices in which multi-sided platforms engage to maximize the value they generate for their communities as well as for themselves in the form of profits. Part III describes sources of negative externalities and relates the problems faced by multi-sided platforms to polities as well as other businesses that must deal with negative externalities created by their customers. Part IV examines the governance methods platforms have developed to manage these problems. It draws on research concerning the business practices of multi-sided platforms in a diverse set of industries and over time. Part $\mathrm{V}$ provides detailed examinations of four economically significant industries that highlight platform governance: social networks, stock exchanges, search engines, and software platforms. Part VI analyzes the legal and policy issues that arise from disputes involving platform governance. It considers the distinction between efficient regulation of negative externalities and anti-competitive exclusion as well as the use of social versus private control over negative externalities in platform communities.

16. See Leo Cendrowicz, The E.U. Probe: Is Google Rigging Its Search Results?, Time, Dec. 2, 2010, available at http://www.time.com/time/business/article/0,8599,2034138,00.html; Companies Ask EU Commission To Step in On Google Search Ranking Complaint, ITPROPORTAL (Feb. 24, 2010), http://www.itproportal.com/2010/02/24/companies-ask-eu-commissionstep-google-search-ranking-complaint/; Claire Cain Miller, Texas Probes Google on Ranking of Search Results, N.Y. TIMES, Sept. 3, 2010, available at http://www.nytimes.com/2010/ 09/04/technology/04google.html?adxnnl=1\&adxnnlx=1314113487-4SfkO0V/SuFxNfcRM dHkbQ; Kinderstart Sues Google Over Lower Page Ranking, REUTERS, Mar. 19, 2006, available at http://www.usatoday.com/tech/news/2006-03-19-google-kinderstart_x.htm. 


\section{MULTI-SIDED PLATFORM STRATEGIES FOR INCREASING VALUE}

eBay creates value through the well-known process of exchange. An individual finds an antique sewing machine in their attic but places little value on it. Another individual collects antique sewing machines. eBay provides a platform for those two individuals to find each other and make a trade. The collector pays money to the sewing machine owner and the collector gets the sewing machine. They are both better off as a result. The sewing machine owner could have sold his machine to an antique store and the collector could have gone to antique stores to find the sewing machine. The ecommerce platform can provide a more efficient means of commerce in antique sewing machines because it can aggregate the demand of many antique sewing machine owners and many buyers and help bring them together to engage in trades.

All multi-sided platforms exhibit the same basic features that we see with eBay. Although platforms can have more than two distinct groups of users, ${ }^{17}$ it is helpful to describe these basic features for a two-sided platform.

First, the platform brings together two types of users that can generate value by coming together. For example, a platform might bring together a man and a woman who are looking for companionship, a sender and receiver of money, a mobile software application developer and a mobile phone user, a search engine user and an advertiser, or many other combinations. These two types of users have interdependent demand functions for platform services in the sense that the demand by members of one group for the platform depends positively on the ability to access and engage in value exchange with members of the other group. ${ }^{18}$

17. Facebook, for example, is a four-sided platform. It is a communications platform for senders and receivers of information. This communications platform is also open to advertisers who want to reach the people that are using Facebook to communicate with each other. It is further made available to entrepreneurs who develop software applications - such as social games - that run on Facebook. There are interdependencies among these four groups of economic users. Facebook, Inc., Registration Statement, supra note 13, at 1.

18. The two types of users do not necessarily need to value each other. It is sufficient that it is possible to create net value by putting them together. A company may value presenting advertising to a consumer but the consumer may be indifferent to the advertising or even willing to pay to avoid it. So long as the value of presenting advertising to the consumer is greater than the cost to the consumer of receiving it, there are potential gains to trade. The role of a platform for advertising-supported media is to "pay" the consumer to be exposed to advertising by providing content. In effect, the media platform owner uses some of the money that the advertiser is willing to pay to reach a user to fund content creation that incentivizes users to be exposed to advertising in return for "free" media content. 
Second, the platform provides a number of services to reduce the transactions costs for these users to come together and to exchange value. Those services could include facilities to search and match users, to figure out exchange values, and to settle transactions. A typical financial exchange, for example, helps agents find counterparties to a trade and provides facilities for them to consummate a trade in addition to many other complementary services.

Third, the platform owner maximizes profit by choosing prices and other strategic variables that recognize the interdependencies between the two groups of users. The economic literature has focused on pricing policies. ${ }^{19}$ The profit-maximizing prices must solve a coordination problem between the multiple sides. A group of users will usually place no value on a platform unless one or more of the other groups of users are also on the platform. The profit-maximizing prices may be at or below marginal cost, and may be zero or negative, and therefore reflect a type of subsidy to one side. ${ }^{20}$ (The social welfare maximizing prices have the same characteristics, although there is no guarantee that the privately and socially optimal prices will coincide. ${ }^{21}$ )

In practice, multi-sided platforms use a wide variety of mechanisms to generate value for platform users and to structure how much net value each group of users receives. ${ }^{22}$ Platforms simultaneously determine how to maximize the overall value of the platform for the users and the allocation of this value among both user groups and the platform owner. Slicing the pie differently results in bigger or smaller pies because of the interdependencies between the groups. The platform owner therefore needs to figure out how to slice the pie in order to make the pie as big as possible.

This Part describes how multi-sided platforms maximize and allocate value and thereby provides a framework for understanding the role of governance systems in this process. Section II.A describes the set of tools that platforms have available to them. Section II.B shows how these tools are

19. See, e.g., E. Glen Weyl, A Price Theory of Multi-Sided Platforms, 100 AM. ECON. REV. 1642, 1649-54 (2010) (discussing, in part, various pricing models as they relate to network platforms).

20. Id. at 1652; Jean-Charles Rochet \& Jean Tirole, supra note 4, at 991, 992.

21. The privately optimal prices set by a multi-sided platform may differ from the socially optimal prices if the platform sets prices too high and output too low. But it may also select a pricing structure that does not solve the coordination problem between the groups of users as efficiently as a social planner would. See Alexander White \& E. Glen Weyl, Insulated Platform Competition 10, 19, 29 (NET Inst. Working Paper No. 10-17, 2011), available at http:/ / papers.ssrn.com/sol3/papers.cfm?abstract_id=1694317.

22. See Evans \& SChMALENSEe, supra note 5, at 13-16; Eisenmann, Parker \& Van Alstyne, supra note 5, at 3-7; Boudreau \& Hagiu, supra note 11, at 175. 
used to create value and in particular to generate positive externalities. Section II.C examines the role of value distribution in solving the coordination problem.

\section{A. The Platform ToOLKIT}

Multi-sided platform businesses have a number of tools for solving coordination problems that generate value for users. To begin with, they can devise a platform design that facilitates the interaction of the different types of users. YouTube, for example, recognized a latent demand for online video sharing. To meet this demand it designed a software and hardware platform that enabled people to upload and view videos. It included features that helped people who uploaded videos to find an audience and helped people who wanted to view videos to find ones they would enjoy. ${ }^{23}$

Platforms also provide specific packages of products or services to each type of user to facilitate coordination. As with a single-sided business, the platform has to decide on the optimal combination of product attributes and price. The difference in the case of a multi-sided platform is that offerings that induce users on one side to join the platform and interact often provide value to the users on the other side. ${ }^{24}$ Software platform designers frequently provide software developers with software developer kits (SDKs) and other assistance to facilitate the efficient development of software that works on the platform. ${ }^{25}$ End users benefit from those quality enhancements indirectly.

Prices are an important element of the toolkit for solving coordination problems. The platform may charge users fees for access to and use of that platform. Those prices can be adjusted to achieve an optimal combination of users, and intensity of use, given their demands. That may entail having a higher incremental profit margin from one side than the other. It also may lead to implicit subsidies to some or all users on one side. OpenTable, for example, charges restaurants for participating in its platform and a fee for each reservation made through the platform; individual patrons can make

23. See Glenn Chapman, YouTube Redesigns Website to Keep Viewers Captivated, AFP (Mar. 31, 2010), http://www.google.com/hostednews/afp/article/ALeqM5jfGfKKsiwbxNv8Xo Ubm8ZIRZZWyw (listing design features such as personalized viewing recommendations and modified playlist tools).

24. See Mark Armstrong, Competition in Two-Sided Markets, 37 RAND J. ECON. 668, 668 (2006); Rochet \& Tirole, supra note 6, at 659.

25. See, e.g., SDKs \& Tools - Facebook Developers, FACEBOOK, http://developers. facebook.com/docs/sdks (last visited Feb. 27, 2012); iOS Dev Center - Apple Developer, APPLE, https://developer.apple.com/devcenter/ios/index.action (last visited Feb. 27, 2012); Microsoft SDKs, MiCROSOFT, http://msdn.microsoft.com/en-us/dd299405 (last visited Feb. 27, 2012); SDKs and Downloads, PAYPAL, https://cms.paypal.com/us/cgi-bin/?cmd=_ render-content\&content_ID=developer/library_download_sdks (last visited Feb. 27, 2012). 
reservations and access other additional services such as reviews, directions, and restaurant suggestions for free. ${ }^{26}$ OpenTable presumably decided that in order to coordinate the demands of restaurants and consumers it needed to offer services free to patrons to attract enough consumers to make the platform valuable to restaurants.

Finally, and a central subject of this Article, platforms can develop and employ governance systems that regulate the actions of participants. These systems can rely on implicit or explicit contracts, detection mechanisms, and penalties. Governance systems facilitate coordination and generate value for users by preventing some users from reducing and possibly destroying the value of the platform. OpenTable, for example, can prevent people who have a record of not showing up for restaurant reservations from making further reservations. That increases the value of the platform to restaurants. But it also increases the value of the platform to users since, if OpenTable was an unreliable source of reservations, restaurants might not use it, and a valuable service might therefore not be available to consumers.

\section{B. VAlue CREATION AND EXTERnalities}

These tools are important for achieving the fundamental economic purpose of a platform: to release value by bringing users together. eBay succeeded in doing this by creating a website where sellers could post products for sale, developing an auction mechanism that allowed buyers to bid for those products, providing a convenient payment mechanism that enabled sellers to receive funds from buyers, implementing a rating system that enabled buyers to communicate information about the sellers they dealt with to other buyers, and devising rules to ensure the integrity of the bidding and selling process. One study of eBay found that the buyers obtained consumer surplus that averaged about $\$ 4$ per purchase and totaled more than $\$ 7$ billion in $2003 .{ }^{27}$ The sellers earned surplus as well, equal to the difference between what they netted from buyers and their personal valuations of the goods. $^{28}$

Platforms rely on the tools described above to maximize the value they create for users overall subject to various constraints, including costs. A core challenge is enabling users that can engage in mutually beneficial exchanges

26. See Farhad Manjoo, As OpenTable Booms, Who Gets the Dough?, FAST COMPANY (Apr. 1, 2011), http://www.fastcompany.com/magazine/155/as-opentable-booms-who-gets-thedough.html.

27. See Ravi Bapna, Wolfgang Jank \& Galit Shmueli, Consumer Surplus in Online Auctions, 19 INFO. SYS. RES. 400, 400 (2008).

28. Id. at 405 . 
to find each other. That is partly addressed through platform design. Online dating sites such as eHarmony rely on detailed questionnaires to find matches for people and then have a process through which people can narrow their searches. $^{29}$

The platform also needs to ensure that there are "high-quality" matches in which the users can split significant value. For many multi-sided platforms, the likelihood of high-quality matches increases with the number of participants. To develop thicker markets, platforms use pricing and other tools to drive participation and positive feedback effects. Some stock exchanges, for example, provide subsidies to providers of liquidity. ${ }^{30}$ More liquidity providers attract more liquidity takers that, in turn, drive more liquidity providers.

\section{Value Distribution And CoOrdination}

As these examples illustrate, value creation is intimately connected to value distribution. A platform has to secure the participation of each side in sufficient numbers to generate value. That involves solving a coordination problem. Members of each group of users would benefit from being on the platform but they will not join the platform unless enough members of the other groups join as well.

The economic literature on multi-sided platforms demonstrates the role of the pricing structure and other strategic decisions by the platform in solving this coordination problem. ${ }^{31}$ By tilting the pricing structure so that one side contributes relatively more incremental margin and the other side contributes relatively less incremental margin, the platform can potentially entice enough members of each group to join. ${ }^{32}$ Once they do, positive feedback effects can fuel growth.

These economic models focus, for simplicity, on the prices that agents are charged. ${ }^{33}$ More generally, however, platforms provide net value to members of each group where that net value is the difference between the

29. See eHarmony Membership Options, EHARMONY, http://www.eharmony.com/singles/ servlet/about/membership (last visited Feb. 22, 2012).

30. See NYSE Euronext, Annual Report (Form 10-K), at 22 (Feb. 28, 2011), available at http://www.sec.gov/Archives/edgar/data/1368007/000095012311019827/y86275e10vk.htm.

31. See Daniel F. Spulber, Solving the Circular Conundrum: Communication and Coordination in Internet Markets, 104 Nw. U. L. REV. 537, 538-39 (2010); Caillaud \& Jullien, supra note 4, at 322.

32. See Wilko Bolt \& Alexander F. Tieman, Heavily Skewed Pricing in Two-Sided Markets, 26 InT'L J. INDUS. ORG. 1250, 1250-51 (2008); Rochet \& Tirole, supra note 6, at 659; Marc Rysman, The Economics of Two-Sided Markets, 23 J. OF ECON. PERSP. 125, 130 (2009).

33. See Rysman, supra note 32, at 129. 
total value received and the total cost incurred by that member. Platforms solve the coordination problem through adjusting what users receive ${ }^{34}$ as well as how much they pay. Apple provides many features on its phones that users find attractive. It also provides software developers with an operating system, tools, and a store for selling applications that developers find appealing. ${ }^{35}$

In determining the relative benefits realized by each group of agents, the platform necessarily makes decisions that allocate benefits between different groups of users. All else equal, charging one group less means charging another group more. The point extends beyond pricing. Platforms make design and other decisions that shift the relative benefits between the two sides. Shopping malls, for example, sometimes place anchor stores that attract the most shoppers as far apart as possible, put up and down escalators far apart, and make other physical design decisions to increase the foot traffic in front of stores. ${ }^{36}$ Malls therefore convey an added benefit on the stores who pay for space, while imposing some costs on shoppers who get in for free. ${ }^{37}$ The stringency of the governance system for different types of users, including the penalties imposed, determines, in part, the distribution of value.

\section{BAD BEHAVIOR AND PLATFORM COMMUNITIES}

A negative externality arises when economic agent A imposes costs on economic agent $\mathrm{B}$ that agent $\mathrm{B}$ has neither agreed to bear nor has received compensation for. ${ }^{38}$ These costs arise in many ways and include many forms of behavior that range from the seemingly innocuous to the obviously egregious, as the following examples illustrate.

- At some point when you enter a highway you increase congestion and impose costs on all other drivers.

- A fisherman increases the likelihood that the fishing grounds will be depleted and therefore imposes costs on other fishermen.

- A factory emits smoke that imposes costs on many people who live in the surrounding area.

34. That is, the platform may decide to shift the demand schedule for a group of users to the right or the left by providing more or fewer product attributes that these users value.

35. See iOS Dev Center-Apple Developer, supra note 25.

36. See Malcolm Gladwell, The Terrazzo Jungle, THE New Yorker, Mar. 15, 2004, at $122-24$.

37. For a general analysis of strategies in which platforms increase consumer search costs, see Andrei Hagiu \& Bruno Jullien, Why do Intermediaries Divert Search?, 42 RAND. J. ECON. 337 (2011).

38. See Mankiw supra note 3, at 203-07. 
- An investment manager engages in a Ponzi scheme that will ultimately collapse and harm the later investors.

- A local gang attacks its rivals.

The perpetrator does not bear any costs for imposing the externality and indeed may benefit from it. In the absence of laws and regulations, agents impose high costs on society. As is well known, left unchecked negative externalities reduce consumer welfare. For the examples above, rules that minimize negative externalities include:

- Toll booths or congestion charges that reduce the incentives to drive.

- Pollution taxes or tradable emission permission taxes that limit pollution.

- Fishing limits, including penalties for exceeding one's quota.

- Prison sentences and fines for engaging in investment fraud.

- Numerous criminal penalties for gang violence.

Many of the rules, both civil and criminal, that communities adopt can be viewed as solutions to negative externalities. Polities ban many sorts of behavior on the grounds that they worsen life in the community. Changing social norms alter the costs and benefits, and formal societal rules evolve as a result (for instance, rules defining the boundaries of unlawful pornography).

Platforms create communities of users with shared interests who benefit from interacting together. Successful platforms have identified positive interdependencies between users, figured out how to reduce transactions costs between these users, and determined price and non-price mechanisms for bringing these users together, thereby coordinating them into a community. Some users, however, may impose negative externalities in many of the same ways and for many of the same reasons as in polities. They may engage in behavior that reduces the value of the platform and that cannot be mitigated through pricing structures. As with polities these actions may range from the seemingly innocent to the obviously bad. The negative externalities that occur on multi-sided platforms are similar to those that occur in polities, as we show next. 


\section{A. It Ought to Be A CRIME}

Platform users may engage in various forms of behavior that have no redeeming virtues and that are analogous to practices that are criminal violations in polities. ${ }^{39}$

Platform users may engage in myriad types of fraud and misrepresentation. Fraud may occur when merchants sell counterfeit goods ${ }^{40}$ or accept payment but then do not ship the goods. ${ }^{41}$ Brokers on exchange platforms could engage in front-running-that is, profiting from information on trades placed by clients possibly to the detriment of the client. Firms can encourage their employees to click on a competitor's ads on search engines to impose costs on them. ${ }^{42}$ Misrepresentation may also occur when people lie about their age or their weight on dating sites, ${ }^{43}$ the true nature of a smartphone application, ${ }^{44}$ or the popularity ranking of their websites. ${ }^{45}$ This list does not exhaust the ways in which opportunistic behavior can occur on platforms.

Polities have rules to prevent people from assaulting other people, engaging in bodily harm, committing libel, and causing mental distress. These issues can arise on multi-sided platforms as well. Interactions in nightclubs and other physical and virtual dating venues can result in bodily harm. Craigslist, for example, has been used by sexual predators to meet, and in some cases kill or rape, victims. ${ }^{46}$ Social networks can be used for inflicting

39. See Richard A. Posner, An Economic Theory of the Criminal Law, 85 COLUM. L. REV. 1193, 1195-97 (1985) (framing crimes as market bypasses creating net disutility).

40. See Rob Unsworth, Amazon Marketplace Offering Dangerous Goods, BBC (Dec. 8, 2008), http://www.bbc.co.uk/blogs/watchdog/2008/12/amazon_marketplace_offering_da.html.

41. See Amazon Marketplace and Ebay Fraud, Andre GunTHER PhOTOGRAPHY, http://www.aguntherphotography.com/blog/amazon-marketplace-ebay-fraud.html (last visited Aug. 23, 2011).

42. See Dan Shipe, Is AdWords Click Manipulation Taking Money From Your Pocket?, ARTICLE/.COM (Aug. 29, 2008), http://www.articleslash.net/Internet-and-BusinessesOnline/PPC-Advertising/475634__Is-AdWords-Click-Manipulation-Taking-Money-FromYour-Pocket.html.

43. See Illusion or Deception?? Why do some people misrepresent themselves on dating sites?, EHARMONY ADVICE-MEMBER DisCUSSION FORUM, http://advice.eharmony.com/ boards/dating-advice/dating/50844-illusion-deception-why-do-some-people-misrepresentthemselves-dating-sites-3.html (last visited Aug. 1, 2011).

44. See Claudine Beaumont, Google remotely deletes Android apps, THE TELEGRAPH (Jun. 25, 2010), http://www.telegraph.co.uk/technology/google/7854560/Google-remotelydeletes-Android-apps.html.

45. See Tom Espiner, Google blacklists BMW.de, CNET News (Feb. 6, 2006), http://news.cnet.com/Google-blacklists-BMW.de/2100-1024_3-6035412.html.

46. See Abby Goodnough, Medical Student Is Indicted in Craigslist Killing, N.Y. TIMES, June 21, 2009, at A13, available at http://www.nytimes.com/2009/06/22/us/22indict.html. 
emotional distress. ${ }^{47} \mathrm{~A}$ highly publicized case involved the use of a social network by Lori Drew to retaliate against a young girl, Megan Meier, who had a disagreement with Drew's daughter. ${ }^{48}$ Using a fake account under which Drew assumed the false persona of a teenage boy, Drew orchestrated an online romance with Meier, had the fake boy become hostile, and eventually suggested that Meier kill herself. Soon after, Meier committed suicide. $^{49}$

Interactions on multi-sided platforms can involve behavior that some users find offensive. This is no different than a regular community. People may incur costs as a result of unwanted exposure to hate speech, pornography, violent images, and other offensive content. Even if they are not exposed to this content, they may dislike being part of a community in which such behavior takes place.

\section{B. POOR AND ASYMMETRIC INFORMATION}

A standard problem in the exchange of value is that one party has information that the other party does not have. Lack of information imposes costs on actual and potential trading partners. In the extreme this can lead to market breakdowns as a result of the "lemons problem." 50 The collapse of the videogame market in the United States in 1983 has been attributed to a lemons problem. Consumers could not distinguish low quality from high quality games before buying them. Producers therefore had incentives to create cheaper low quality games that drove the high quality games out of the market. But consumers did not want to buy video game consoles to run low quality games. $^{51}$

More generally, asymmetric information reduces market efficiency by reducing the likelihood that users will find the matches that maximize the

47. See, e.g., Yancy v. U.S. Airways, Inc., No. Civ. A. 10-983, 2011 WL 2945758 (E.D. La. July 20, 2011) (embarrassing pictures of employee were posted on Facebook); Maremont v. Susan Fredman Design Group, Ltd., No. 10 C 7811, 2011 WL 6101949 (N.D. Ill. Dec. 7, 2011) (employer used employee's personal Twitter and Facebook accounts to advertise while employee was in the hospital).

48. United States. v. Lori Drew, 259 F.R.D. 449 (C.D. Cal. 2009).

49. See Mom: MySpace Hoax Led to Daughter's Suicide, ASsOCIATED PRESS (Nov. 16, 2007), http://www.foxnews.com/story/0,2933,312018,00.html.

50. See George A. Akerlof, The Market for "Lemons": Quality Uncertainty and the Market Mechanism, 84 Q. J. OF ECON. 488 (1970) (owners of cars that are "lemons" are more likely to sell them; since consumers cannot distinguish lemons from good cars, the sale prices of good cars are depressed; that leads owners of good cars not to sell; the market for reselling quality cars is therefore destroyed).

51. See David S. Evans, Andrei Hagiu \& Richard Schmalensee, Invisible ENGINES: How SOFTWARE PlatForms DRIVE INNOVATION AND TRANSFORM INDUSTRIES 124-25 (2006). 
total value from trade. Several studies have found that requiring corporate bond traders to disclose information on trading prices resulted in improved efficiency and substantially lower trading costs. ${ }^{52}$

Opportunistic behavior resulting from asymmetric information may increase the uncertainty for people and companies that are considering using a platform. Traders may prefer platforms that have transparent pricing and social network users may prefer platforms where information about people is reliable.

\section{Congestion and Optimizing Physical Spaces}

Negative externalities can result from increasing the number of users for multi-sided platforms. Physical platforms face congestion problems. A nightclub provides a trivial example. Too many people will make it harder for people to mingle and enjoy themselves. A shopping mall provides a more interesting example. An increase in the number of merchants may increase search costs and therefore harm other sellers as well as buyers.

Multi-sided platforms have to design and manage their spaces to reduce negative externalities as well as to promote positive externalities. Expanding the square footage of a mall to accommodate more stores imposes costs on shoppers who have to walk farther on average. Similar considerations apply to virtual platforms. Search engines need to make decisions on how many results and advertisements to display on each page and in what format. They need to do this to promote positive externalities and also to limit congestion and reduce search costs. ${ }^{53}$

\section{Case In Point: DecorMyEyes}

Vitaly Borker's strategies for selling eyewear on the web highlight almost all these forms of bad behavior; they also provide a lesson in what happens

52. These studies concern the introduction of the TRACE (Trade Reporting and Compliance Engine) system for corporate bonds in the United States. See Hendrik Bessembinder, William Maxwell \& Kumar Venkataraman, Market Transparency, Liquidity Externalities, and Institutional Trading Costs in Corporate Bonds, 82 J. OF FIN. ECON. 251 (2006); Amy Edwards, Lawrence Harris \& Michael Piwowar, Corporate Bond Market Transaction Costs and Transparency, 62 J. OF FIN. 1421 (June 2007); Michael Goldstein, Edith Hotchkiss \& Erik Sirri, Transparency and Liquidity: A Controlled Experiment on Corporate Bonds, 20 REV. OF FIN. STUD. 235 (2007). For a summary, see Hendrik Bessembinder \& William F. Maxwell, Transparency and the Corporate Bond Market, 22 J. OF ECON. PERSP. 217 (2008).

53. Eye-tracking studies of how consumers use search engines reveal that both the quality of the consumer experience and the attention paid to advertising varies substantially with the layout and organization of the search results page. See, e.g., CatalystGroup, Google vs. Bing: Search Engine Preference, June 2009, available at http://www.catalystnyc.com/cofactors/ wp-content/uploads/2009/06/catalyst-eye-tracking-bing-vs-google-may-2009.pdf. 
when platform governance is imperfect. Borker learned that search engines did not distinguish between good and bad cites to his website. ${ }^{54} \mathrm{He}$ responded to complaints with highly offensive emails and posts that generated even more complaints. ${ }^{55}$ He told a New York Times reporter, "I've exploited this opportunity because it works. No matter where they post their negative comments, it helps my return on investment. So I decided, why not use that negativity to my advantage?" 56

Borker, who used the aliases Tony Russo and Stanley Bolds, received many complaints because he engaged in fraudulent behavior, including adding spurious charges to customers' payment cards. ${ }^{57}$ When people pursued their complaints against him, Borker-sometimes using one of his aliases - threatened them with bodily harm including death or rape. ${ }^{58} \mathrm{He}$ threatened one customer with sexual violence when she said she was going to have her credit card issuer reverse an overcharge. ${ }^{59}$ Borker later sent the customer pictures of the outside of her apartment building in a further attempt to intimidate her. ${ }^{60}$

Borker relied heavily on two web platforms for these practices. He fulfilled his orders from sellers on eBay who were directed to ship to his customers. ${ }^{61} \mathrm{He}$ also used search engine rankings to drive business. ${ }^{62}$ Initially, the governance systems of these platforms failed to thwart him. In the case of search results, he had discovered a way to manipulate the search algorithm as well as the detection methods then in place for identifying efforts to distort results. ${ }^{63}$ After the story was reported, Google developed an algorithm to detect efforts to increase search rankings by encouraging bad comments. ${ }^{64}$

54. See David Segal, A Bully Finds a Pulpit on the Web, N.Y. Times, Nov. 28, 2010, available at http://www.nytimes.com/2010/11/28/business/28borker.html.

55. Id.

56. $I d$.

57. See id.

58. See "Google hitman": Eyeglasses seller "threatened customers with rape and murder to elevate his website on search engines," DAILY MAIL, May 15, 2011, available at http://www.dailymail.co.uk/news/article-1387310/Google-hitman-Vitaly-Borker-threatenedcustomers-rape-murder.html.

59. See Segal, supra note 54.

60. Id.

61. See id.

62. See id.

63. Id.

64. Alyson Shontell, Making Customers Hate You Makes Google Love You, Bus. INSIDER, Dec. 3, 2010, http://www.businessinsider.com/making-customers-hate-you-makes-googlelove-you-2010-12. 
Meanwhile, public law took care of Borker, who pled guilty to wire fraud, mail fraud, and sending threatening communications. ${ }^{65}$

\section{E. Bad BeHaVior and PlatForm VAlue}

Many forms of bad behavior, such as fraud and misrepresentation, clearly reduce the value of the platform. Like many forms of criminal behavior, this behavior has no redeeming virtues. However, some behavior that imposes costs on other participants in the platform and therefore seems "bad" also provides benefits. When these benefits outweigh the costs, the behavior does not generate negative externalities, on net, and therefore is not behavior that the platform would necessarily want to discourage.

That could be the case, for example, with asymmetric information in some cases. Users may need incentives to invest in acquiring information, and the ability to capitalize on their control over that information may provide those incentives. The benefits from increased dynamic efficiency from investment in gathering information may outweigh the losses from lower static efficiency as a result of not sharing that information. ${ }^{66}$ Greater transparency on social networks has its costs too. Information that increases the value of one relationship may decrease the value of another relationship. ${ }^{67}$

\section{DEALING WITH BAD BEHAVIOR}

Multi-sided businesses could simply rely on civil and criminal law and government regulation to deal with the negative externalities that arise on their platforms. Users have recourse to laws involving breach of contract, fraud, market manipulation, assault and battery, and intentional infliction of emotional distress to deal with many of the problems discussed above. ${ }^{68}$ Laws and regulations have tackled asymmetric information problems through

65. Kathy Kristof, Online Retailer Guilty of Fraud, Threats, CBS MONEYWATCH (Dec. 6, 2010), http://moneywatch.bnet.com/saving-money/blog/devil-details/onlineretailer-charged-with-fraud-threats/3478/.

66. Studies of increased transparency in bond markets found that transparency may have reduced liquidity, leading to some markets being inefficiently thin. Hendrik Bessembinder \& William Maxwell, Markets: Transparency and the Corporate Bond Market, $22 \mathrm{~J}$. OF ECON. PERSP. 217, 228-29 (2008).

67. See Danah Boyd, None of This Is Real: Identity and Participation in Friendster, in Structures of Participation in Digital Culture 132, 145 (Joe Karaganis ed., 2007). For the record, Ms. Boyd does not capitalize her first or last name. This imposes a negative externality on people, like me, who then have to deal with editors and readers who are not in on the deviation from grammatical rules.

68. See, e.g., Complaint at 8, Thompson v. Facebook, No. 1:09-cv-22927-KMM (S.D. Cal. Sept. 29, 2009); First Amended Complaint, Yingling v. eBay, No. C-09-01733 (N.D. Cal. June 16, 2009). 
mandatory disclosure laws, mandatory cooling-off periods, and return policies. ${ }^{69}$ New multi-sided platform businesses can give rise to novel issues such as cyber bullying. Governments can pass new laws in response to this, as the State of Missouri did after the Megan Meier suicide and the unsuccessful prosecution of the instigator. ${ }^{70}$

Some multi-sided platforms have, however, developed their own mechanisms for dealing with bad behavior. They adopt rules for the users on one or more sides of the platform, institute reporting and detection mechanisms in order to uncover violations of these rules, require evaluations of the evidence through mandatory arbitrations, impose penalties, and sometimes even allow appeals from the initial evaluation as shown below.

There are two reasons for platforms not to rely entirely on the public sector. The first is that the platforms generally are able to enforce rules to reduce negative externalities more rapidly and efficiently than the public sector. $^{71}$ Search engines can develop algorithms for detecting efforts to manipulate search rankings and de-list websites that are trying to take advantage of users or demote them in the search rankings. An e-commerce platform can decide after a few complaints to drop a merchant from its site, and exchanges can debar traders. In addition to the inherent differences in the efficiency of public and private actors, the fact that the public sector must give people and businesses rights of due process (which society has found necessary to check the government's enormous powers over its citizens) necessarily makes the enforcement of laws and regulations by the public sector more time consuming and expensive. A platform owner, for example, can monitor a user's behavior without showing probable cause. A platform can therefore provide value to its community by providing an efficient governance system.

The second reason for a platform to take action is that public laws and regulations may be incomplete when it comes to policing negative externalities on platforms. The government may not have recognized (or recognized too slowly) a problem such as cyber bullying on social networks or the opportunistic inflation of search rankings. It may have other objectives or obligations, such as the protection of free speech that deter or preclude it

69. See, e.g., Truth in Lending Act, 15 U.S.C. \ 1601 (1968); Magnuson-Moss Warranty Act, 15 U.S.C. $\int 2301$ (1975); FTC Cooling-Off Rule, 16 C.F.R. \ 429 (1995).

70. See Associated Press, Mo. Internet Harassment Bill Passed after MySpace Suicide, USA TODAY, Jul. 1, 2008, available at http://www.usatoday.com/news/nation/2008-06-30internet_N.htm.

71. For a related discussion see Henry E. Smith, Property and Property Rules, 79 N.Y.U L. REV. 1719 (2004); Henry E. Smith, Exclusion and Property Rules in the Law of Nuisance, 90 VA. L. REV. 965 (2004). 
from enforcing rules that private parties may decide to adopt themselvessuch as against hate speech or pornography. The government may also decide not to pursue various problems simply because the cost of doing soincluding unintended consequences that often result from government laws and regulations-exceeds the likely benefits. The platform has more information about the problems, can react more quickly to them, and can modify its governance mechanisms more quickly if they are not working or are having perverse effects.

A private platform does not, of course, have the same range of instruments available to it as a public entity does. It cannot issue search warrants, engage in wiretaps, conduct dawn raids, put people in jail, or debar wrongdoers from anything other than participating on the platform itself. Unless it invokes public laws, for example by filing a breach of contract claim, it cannot compel the discovery of information for an investigation. Nor can a private platform collect penalties unless it requires a bond or collects it as a condition of the agent having continued access to the platform.

In fact, all of the platform's powers, aside from contract and other rights that it would have to enforce in public courts, rest in its property rights over the platform including, most importantly, its ability to exclude. This section elaborates on this point before turning to an overview of platform governance concerning negative externalities.

\section{A. The Property Rights Framework}

Strahilevitz has presented a useful framework for analyzing how property rights can be used to deal with information asymmetries. ${ }^{72}$ The right to exclude has four subordinate rights: (1) the Hermit's Right to keep all agents off the owner's property; (2) the Bouncer's Right to admit agents selectively to the property and therefore to eject agents selectively from the property; (3) the Exclusionary Vibe which uses social and psychological sanctions to discourage some agents from entering the property; and (4) the Exclusionary Amenity which uses club goods to sort desirable and undesirable entrants. ${ }^{73}$

72. See Lior Jacob Strahilevitz, Information Asymmetries and the Rights to Exclude, 104 MiCH. L. REV. 1835, 1837 (2006). Boudreau \& Hagiu, supra note 11, at 169, emphasize the "Bouncer's Right" identified by Strahilevitz. However, in the context of their analysis of the general solution by platforms of market failures, platforms also use the Exclusionary Vibe (e.g., a magazine for a niche audience) and the Exclusionary Amenity (e.g., a discount department store as an anchor in a mall).

73. Strahilevitz, supra note 72 , at 1837. 
He argues that the last three of these rights are substitutable methods for maximizing the value of the property. ${ }^{74}$

Strahilevitz's framework generally maps well into the tools that multisided platforms use to optimize the value of their property. Some platforms exercise the Hermit's Right through design decisions ${ }^{75}$ and start out life single-sided. For example, the Palm Pilot created their own applications and did not allow others to do so for about eighteen months after its launch. ${ }^{76}$ Almost all of the strategies for reducing negative externalities depend on the exercise of the Bouncer's Right. This is discussed in more detail in the next Section. The Exclusionary Vibe and Exclusionary Amenity are used by many platforms to attract a particular group of users on one side that is valuable to a particular group of users on the other side. There is a blurry line between the two strategies for multi-sided platforms. Niche magazines are an example. Runners World is designed to attract runners and companies that want to sell to them. ${ }^{77}$ The vibe and amenity go together-companies that want to advertise to runners are attracted to the amenity by an aggregation of runners created by the vibe generated by the content (not to mention the title).

Smith, who Strahilevitz builds on, argues that property rights and governance are substitutes from the standpoint of maximizing social welfare. ${ }^{78}$ The idea is that there are some market failures that governments can resolve precisely through laws and regulation. There are others that private parties can solve through the blunt instrument of property rights because they have better access to information.

Multi-sided platforms can be analyzed in this framework. They represent the interests of a community - albeit a private and voluntary one-just as a government does, and are perhaps even more motivated than the government to maximize, at least approximately, the social wealth of that community. The platform owner also has incentives to take the long-run interests of the community into account since it is maximizing the long-run value for itself or its shareholders. The platform often uses, among other

74. Id. at 1861 .

75. See Evans, Hagiu \& SCHMALENSEE, supra note 51, at 168-69.

76. $I d$.

77. See RUNNER'S WORLD, http://www.runnersworld.com (last visited Feb. 29, 2012). The website homepage features a banner ad for the book MARATHON: The Ultimate Training Guide; the Shoes \& Gear section includes a Store Finder tool, and the Nutrition \& Weight Loss section displays a side ad for the book The Lean Belly Prescription: The fast and foolproof diet and weight-loss plan from America's top urgent-care doctor.

78. See Henry E. Smith, Exclusion Versus Governance: Two Strategies for Delineating Property Rights, 31 J. OF LEGAL STUD. S453 (2002). 
things, a governance system for dealing with negative externalities among platform users. But for the platform, property rights-and the bundle of rights to exclude identified by Strahilevitz, and in particular the Bouncer's Right—are necessary for governance.

\section{B. SELECTIVE EXCLUSION}

Platform governance generally consists of a set of rules for platform agents that proscribe certain actions by these agents or compel certain other actions. These rules can be used to increase positive externalities. For example, card networks require banks to insert acceptance marks on cards and merchants to post acceptance marks; this makes it easier for cardholders and merchants who use the same payment method to find each other. ${ }^{79}$ More commonly, though, rules are designed to eliminate or mitigate negative externalities. These rules need to have consequences to be meaningful. Those consequences can involve partial or full exclusion from the platform, or its benefits, for some period of time, perhaps forever. ${ }^{80}$ The platform also needs to be able to detect violations for these rules to be meaningful. That could be a combination of proactive detection or response to complaints. And finally, the platform may employ a process in which suspected wrongdoers can plead their cases, or at least convey potentially useful information, and possibly an appeals process.

The Portobello Road Antique Dealers Association in London provides an example. ${ }^{81}$ A number of antique dealers have located on Portobello Road in London. That is a common situation in the economic geography of agglomeration and is an example of a platform that emerges naturally without any necessary ownership. But some of these dealers decided to start an association to address common issues. One of those issues involved creating and maintaining a high quality brand. For this purpose they adopted a code of ethics. Members are required to post the price and as much information as possible about the item. The code also prohibits members from misrepresenting antiques or misleading their customers. The association also provides a dispute resolution service for customers who believe they have gotten a bad deal. Members who violate the code can be "bounced" from the

79. See, e.g., Visa International Operating Regulations, VISA, October 15, 2011, at 153-54 (marks required on cards) and 434 (marks required at point-of-sale), http://usa.visa.com/merchants/operations/op_regulations.html.

80. See, e.g., Statement of Rights and Responsibilities, FACEBOOK, http://www.facebook.com /legal/terms (last visited Feb. 29, 2012); Your User Agreement, EBAY, http://pages.ebay.com/ help/policies/user-agreement.html (last visited Feb. 29, 2012) [hereinafter eBay User Agreement].

81. See EVANS \& SCHMALENSEE, supra note 5, at 110-11. 
association and therefore lose access to the credibility signal that the association provides to customers. ${ }^{82}$

Other commerce platforms have similar rules. eBay has a detailed user agreement for buyers and sellers. ${ }^{83}$ It tells users that eBay has the right to restrict their access to the site in various ways, including full termination, if the user abuses the site. ${ }^{84}$ The user agreement includes a mandatory dispute resolution mechanism for buyers and sellers. eBay has detailed rules for buyers $^{85}$ and sellers ${ }^{86}$ that prohibit a variety of actions that could result in negative externalities. A major concern is the integrity of the auction process. For example, buyers are not allowed to bid on items offered by sellers they know personally. Sellers who are banned from the site can appeal that decision. ${ }^{87}$

These types of rules solve several possible externality problems. Consider the case of payment cards. Card users likely value certainty over the prices they will pay when they use their cards at accepting merchants; they also likely value the certainty that merchants with a sign indicating they accept the network's card actually do so. To the extent that merchants impose surcharges or refuse cards, they impose costs not only on the cardholders affected by these decisions but also cardholders generally through the introduction of uncertainty. In addition, merchants that surcharge cards or

82. "If it is reported that a member violates the code, we interview that member to hear he/she has to say and take action accordingly. This may be a verbal or written warning not to do it again or more severe action including expulsion from the Association." E-mail from Leyla Ozyurt, Portobello Market Association, to Jacqueline Murphy, Consultant, Market Platform Dynamics (Mar. 18, 2012, 13:05:00 CST) (on file with author).

83. See eBay User Agreement, supra note 80.

84. The user agreement says "Without limiting other remedies, we may limit, suspend or terminate our service and user accounts, prohibit access to our sites and their content, services and tools, delay or remove hosted content, and take technical and legal steps to keep users off the sites if we think that they are creating problems or possible legal liabilities, infringing the intellectual property rights of third parties, or acting inconsistently with the letter or spirit of our policies (for example, and without limitation, policies related to shill bidding, conducting off-eBay transactions, feedback manipulation, circumventing temporary or permanent suspensions or users who we believe are harassing our employees or other users). Additionally, we may, in appropriate circumstances and at our discretion, suspend or terminate accounts of users who may be repeat infringers of intellectual property rights of third parties. We also reserve the right to cancel unconfirmed accounts or accounts that have been inactive for a long time, or to modify or discontinue eBay sites, services or tools." Id.

85. See Rules for Buyers-Overview, EBAY, http://pages.ebay.com/help/policies/buyerrules-overview.html (last visited Feb. 29, 2012).

86. See Rules for Sellers-Overview, EBAY, http://pages.ebay.com/help/policies/sellerrules-overview.html (last visited Feb. 29, 2012).

87. See Help_Suspended accounts, EBAY, http://pages.ebay.com/help/account/ suspended-accounts.html (last visited Apr. 10, 2012). 
refuse to accept cards selectively may impose costs on other merchants by degrading the overall quality of this form of payment. There is a further negative externality. Some merchants may use the desire to pay with a card as a method for implementing price discrimination. On average, consumers that want to pay with cards are less likely to have another equally convenient payment method and may therefore be willing to pay a higher price to the merchant. This may be a profit-maximizing strategy, especially when it is unlikely the consumer will be a repeat customer (e.g., a tourist).

A common problem for dating sites involves preventing unwanted approaches. Sites such as eHarmony check their users against lists of registered sex offenders. ${ }^{88}$ They also do not allow users to search for profiles. Instead the site matches profiles using its algorithm and pre-screens each candidate. An introduction is made only if both parties agree to this. At that point, individual identifying information is made available to both parties. ${ }^{89}$ eHarmony also provides a service whereby users can report problems and eHarmony can take actions including removing offending individuals from its service. $^{90}$

While many multi-sided platforms have governance systems to limit negative externalities, others do not or have quite limited ones. Advertisingsupported media tend to have very limited screening of ads. They often prohibit advertisements that would be offensive to their readers. ${ }^{91}$ In the next

88. See Safety Tips, EHARMONY, http://www.eharmony.com/safety/tips (last visited Feb. 29, 2012). The "Do Your Own Research" Section states that eHarmony employs screening tools, including checking U.S. subscribers against sex offender registries in the United States. See id.

89. See eHarmony Tour, EHARMONY, http://www.eharmony.com/tour (last visited Apr. 10, 2012); eHarmony is More than Traditional Dating Sites, EHARMONY, http://www.eharmony.com/why/ (last visited Apr. 10, 2012).

90. Pam Holmgren, A Safety Reminder from eHarmony, EHARMOnY Blog (Apr. 18, 2011), http://advice.eharmony.com/blog/2011/04/18/a-safety-reminder-from-eharmony-2/ ("If you ever are concerned about one of your matches for any reason, please send an email to matchconcerns@eharmony.com so we can investigate and take appropriate action. We have a team dedicated to our members' safety and close accounts immediately when we receive a credible complaint about someone's suspicious behavior. We'll notify you whenever someone is removed from the service, so please pay attention to those emails if you ever receive one and stop all communication with that person.”).

91. The Chicago Tribune does not intentionally take advertisements for sex services, but the paper does not police false advertising or provide readers with any mechanism for complaining about advertisers they have interacted with as a result of seeing an advertisement in the media. See Advertiser Services-How It Works, CHI. TRIB., http://www.chicagotribune.com/advertiser/how-it-works/ (last visited Mar. 1, 2012). Craigslist had, in the past, accepted the advertising of adult services on its site, but it has since removed the category. See Claire Cain Miller, Under Fire From Critics, Craigslist Blocks 
section we will see how MySpace, the leading social network site in the United States in the mid 2000s, had a very limited governance system initially and imposed some rules only in response to significant media and governmental pressure.

The rules discussed above are generally enforced using the Bouncer's Right. Users that violate the rules can be ejected from the platform. Some people_-such as known sexual predators on dating sites-are barred from entering the platform in the first place.

\section{INFORMATION AND TRANSPARENCY}

Multi-sided platforms also provide information to deal with negative externalities. That has become increasingly common as a result of the development of Internet and web technologies. eBay Motors has reduced the lemons problem by providing ratings on automobile dealers. eBay provides a mechanism for consumers to rate merchants after they have made a purchase. They send consumers reminders to provide these ratings. ${ }^{92} \mathrm{~A}$ consumer can minimize the likelihood of getting a car with undisclosed problems by buying from an automobile dealer that has a very high rating. Automobile dealers presumably know that a negative rating can have a serious effect on their ability to make sales. The reviews limit the ability of automobile dealers to take advantage of consumers by exploiting asymmetric information. They also limit the ability of dealers to impose negative externalities on each other since good dealers tend to drive out bad dealers as consumers lower their expectations on the quality of cars they get from bad dealers. ${ }^{93}$ Similar rating systems are common now on web-based platforms that connect buyers and sellers. ${ }^{94}$

Access to 'Adult Services' Pages, N.Y. Times, Sept. 4, 2010, available at http://www.nytimes.com/2010/09/05/technology/05craigs.html.

92. See eBay Updates to Payment and Leave Feedback Reminder Emails Sent to Buyers, EBAY, http://pages.ebay.com/sellerinformation/news/reputationemails.html (last visited Feb. 29, 2012) ("Because the Feedback system has such an important role on eBay in measuring a seller's quality of service, an email reminding buyers to leave Feedback is sent by eBay as a consistent part of all transactions.”).

93. For example, in recently purchasing an automobile on eBay, the author found that it was possible to limit consideration to dealers with 100 percent satisfaction ratings. There was no need to consider dealers that had complaints.

94. See, e.g., Rating a Seller, AMAZON, http://www.amazon.com/gp/help/customer/ display.html?nodeId $=537806$ (last visited Feb. 29, 2012); Feedback scores, stars, and your reputation, EBAY, http://pages.ebay.com/help/feedback/scores-reputation.html (last visited Feb. 29, 2012); How do I leave feedback?, ETSY, http://www.etsy.com/help/article/102 (last visited Feb. 29, 2012). 
The provision of information is often an application of the Exclusionary Vibe. The multi-sided platform is exercising its property rights when it collects information from users on the platform about other users and makes that information publicly available. It does not bounce users that engage in opportunistic behavior, or users that create negative externalities as a result of the lemons problem, but it does establish a mechanism that tends to drive low quality users off of the platform.

The Exclusionary Vibe can be used to reduce negative externalities in other ways than the direct provision of information. An example is JDate, which advertises itself as the premier Jewish singles community. ${ }^{95}$ One would expect that having Gentiles would impose negative externalities on Jews looking for other Jews since it would increase their search costs and reduce matching efficiency. It would not appear that the site has any way to verify religious or ethnic background, so it could not specifically exclude non-Jews. But it can establish a vibe that this is a site meant for Jewish men and women to meet each other. It also encourages Gentiles to identify themselves. ${ }^{96}$

\section{GOVERNANCE REGIMES FOR KEY PLATFORMS}

Three economically prominent platform types-social networks, stock exchanges, and search engines-illustrate the role of governance systems, the methods that are chosen for these governance systems, and the tensions that governance systems create between the platform sides.

\section{A. SOCIAL NETWORKS}

The evolution of social networks from Friendster to MySpace to Facebook shows the role of negative externalities in platforms that are perhaps the closest to traditional communities and shows how different governance systems can affect platform value. Negative externalities played a role in the downfall of both Friendster and MySpace. Meanwhile, Facebook - which has almost a billion active monthly users around the world-continues to thrive because it created and emphasizes a "nice" community that prohibits foul language, fake identifies, and pornography.

95. See JDATE, http://www.jdate.com/ (last visited Aug. 1, 2011).

96. See Lisa Scherzer, Looking for Mr. Goodstein: When Gentile Singles Seek Jewish Mates, INTERFAITHFAMILY.COM, http://www.interfaithfamily.com/relationships/interdating/ Looking_for_Mr_Goodstein_When_Gentile_Singles_Seek_Jewish_Mates.shtml (last visited Feb. 29, 2012) (quoting Gail Laguna, vice president of communications at MatchNet.com, owner of JDate: “ When a member sets up a profile on JDate, they are asked to put down their religious affiliation; there is an option to pick another religious stream,' she said. 'If they are non-Jews, we encourage them to put down that they're not Jewish and not pretend they're of the Jewish faith' "). 
Although initially successful, Friendster's belated attempt to impose a private governance regime ultimately led to its failure. Friendster launched in 2002 and grew rapidly. ${ }^{97}$ Jonathan Abrams, its founder, thought the dating sites of the time were "too anonymous and creepy." 98 They also provided inaccurate information. As he put it, "[w]ith JDate, [for example,] a guy is almost bound to be twenty pounds heavier or twenty years older than he is in his photo." 99 To solve this problem Abrams developed Friendster so that people could link to friends and see friends of friends. "We're trying to make the process more accountable," he said. ${ }^{100}$ "People will put a more accurate picture of themselves on Friendster because you know your friends will see it." ${ }^{101}$ By 2003 Friendster had more than three million users. ${ }^{102}$

However, the use of Friendster to create fake profiles quickly became popular. "Fakesters" - as they were called-made up fictional personas for themselves. According to Danah Boyd, "Fakesters were created for famous people, fictional characters, objects, places and locations, identity markers, concepts, animals, and communities."

Friendster's management soon recognized that Fakesters posed burdens on the social networking site. Boyd writes, "[a]lthough most participants loved the playful aspect of Fakesters, it further complicated the network structure and created an appearance of unreliability, which irritated both the company and individuals intent on using Friendster for serious networking." "104 In addition, some of the Fakesters attracted massive traffic, which caused congestion on the site's servers. Recognizing these negative externalities, Friendster's owners decided to purge the Fakesters, who consumed significant amounts of scarce server capacity and created noise. ${ }^{105}$

In response to Friendster's purge, the Fakesters organized themselves and attempted to reinsert their profiles. They also sought revenge on Friendster by having "Fraudsters" masquerade as real people. Friendster's growth slowed considerably as a result of its continued efforts to exclude

97. See Boyd, supra note 67, at 133.

98. See Finding Love Online, Version 2.0, Bloomberg Businessweek, Jun. 10, 2003, http://www.businessweek.com/technology/content/jun2003/tc20030610_4294_tc104.htm.

99. Julia Angwin, Stealing MySpace: The Battle to Control the Most Popular WEBSITE IN AMERICA 50 (2009).

100. Id.

101. $I d$.

102. See A Cautionary Tale, FAST COMPANY (Dec. 19, 2007), http://www.fastcompany. com/magazine/115/open_features-hacker-dropout-ceo-cautionary-tale.html.

103. Boyd, supra note 67, at 148.

104. Id. at 150 .

105. See id. at 151. 
people from the network. One could conclude that Friendster's downfall resulted from imposing and enforcing a governance regime. As will soon be clear, a more plausible interpretation is that Friendster's failure to impose rules against fake identities at the outset resulted in significant negative externalities.

Unlike Friendster, MySpace embraced a lax policy towards the reliability of consumer information. This policy helped its early rise but led to the website's ultimate downfall. MySpace was founded in 2003: ${ }^{106}$ its founders thought that Friendster was making a mistake in preventing people from having fake identities. ${ }^{107}$ The website quickly attracted people who were being deleted from Friendster, including Tila Tequila_a Vietnamese modelwhose real surname was Nguyen. Tila Tequila attracted a larger following on Friendster in part by posting provocative photos of herself. Friendster deleted her account several times, and as a result she moved to the more welcoming MySpace. ${ }^{108}$ Others followed. MySpace grew very quickly, overtook Friendster, and became one of the most heavily trafficked sites on the Internet for a period of time. ${ }^{109}$

MySpace's laissez faire governance policies soon caused problems. Because MySpace did not require or encourage people to provide reliable information, it attracted child sex predators as well as minors who lied about their ages. The site also did little to discourage people from having user pages with "partial nudity, obscenity, crude sexual jokes, and other objectionable content." MySpace gained a reputation as a "vortex of perversion" as a site that was not very safe-like a city's red light district.

As the popularity of the site attests, a large number of people liked the risqué nature of MySpace. Yet, advertisers-who provided the principal

106. See Company Overview of MySpace, Inc:: Snapshot, BloOMBERG BusINESSWEEK http://investing.businessweek.com/research/stocks/private/snapshot.asp?privcapId=120412 (last visited Mar. 1, 2012).

107. See Danah Boyd, Friends, Friendsters, and Top 8: Writing Community into Being on Social Network Sites, FIRST MONDAY (Dec. 4, 2006), http://firstmonday.org/htbin/cgiwrap/ bin/ojs/index.php/fm/article/view/1418/1336.

108. See Lev Grossman, Tila Tequila, Time, Dec. 16, 2006, http://www.time.com/ time/magazine/article/0,9171,1570728,00.html.

109. It was one of comScore's top fifty web properties in the United States by April 2005. See JULIA ANGWIN, supra note 99, at 126.

110. See id. at 181.

111. See Felix Gillette, The Rise and Inglorious Fall of MySpace, BLOOMBERG BusINESSWEEK, Jun. 27, 2011, at 52, 58, available at http://www.businessweek.com/ magazine/content/11_27/b4235053917570_page_5.htm. 
source of revenue for MySpace ${ }^{112}$ — did not. Companies did not want to risk displaying their brands on pages with objectionable content. With limited interest from major brands in buying advertising inventory, MySpace moved its advertising inventory to other advertising networks, including Google's context-based advertising network. ${ }^{113}$ These networks inserted low-price advertisements automatically into areas MySpace made available. ${ }^{114}$ Not surprisingly_ given the content of the site, the low prices for the advertising inventory, and some of the people attracted to MySpace-a number of the advertisements that were displayed were also related to things that some people would find objectionable.

Facebook-which started in February 2004-took a very different approach than either Friendster or MySpace. It adopted strict rules to prevent bad behavior despite being initially targeted to, and started by, college kids. Like Friendster it focused on creating a platform for people to manage their relationships with friends. But Facebook required people to use their real identities. It initially limited access to the site to people with valid university email accounts ending in ".edu," starting with harvard.edu. It then expanded to selected groups, including businesses with identifiable email addresses. When it opened to the world in September 2006, Facebook had 500 regional networks. ${ }^{115}$ Although this approach made it more difficult for people to use fake identities on Facebook it was still possible. Facebooklike Friendster-deletes the pages with fake identities that violate its terms of service. For example, in 2007 it deleted the pages that people had set up to represent brands that were not allowed at the time. ${ }^{116}$

Facebook has also taken active steps to limit negative externalities on its site that would limit its appeal to new users and to advertisers who are considering inserting messages on its pages. Its terms of service prohibit

112. Is Myspace Free?, MYSPACE.COM, (Aug. 22, 2008), available at http://web.archive.org/web/20080822094142/http://www.myspace.com/Modules/Help/ Pages $/$ HelpCenter.aspx?Category $=1 \& Q u e s t i o n=33$.

113. See Google signs $\$ 900 m$ News Corp Deal, BBC News, Aug. 7, 2006, http://news.bbc.co.uk/2/hi/business/5254642.stm.

114. See Kevin Kelleher, MySpace and Friends Need to Make Money. And Fast., WIRED, Mar. 24, 2008, available at http://www.wired.com/techbiz/it/magazine/16-04/bz_socialnetworks.

115. See Janet Kornblum, Facebook Will Soon be Available to Everyone, USA TODAY, Sept. 11, 2006, http://www.usatoday.com/tech/news/2006-09-11-facebook-everyone_x.htm.

116. See Niall Kennedy, Facebook Cleanses Pages of Supposed Fakesters, NiALL KENNEDY'S WEBLOG (Dec. 1, 2007, 8:54 PM), http://www.niallkennedy.com/blog/2007/12/facebookpages-deletions.html. Note, however, that Tila Tequila has a fan page (perhaps the name is no longer viewed as fake) but with decidedly less provocative pictures than she has on MySpace. See Tila Tequila's Albums, FACEBOOK, http://www.facebook.com/Tila/photos (last visited Apr. 16, 2012). 
various actions including bullying, intimidating, or harassing any user, posting content that is "hateful, threatening, or pornographic, incites violence; or contains nudity or graphic or gratuitous violence." 117 As of April 2009, 150 (eighteen percent) of the company's 850 employees focused on policing the website for offensive content. ${ }^{118}$ They would delete photos such as a "girl blowing an epic cloud of pot smoke" that violated the social norms the company wanted to promote. ${ }^{119}$

At Facebook, the range of policed activity is broad. A division called User Operations looks at all content that users say is harassing (via "report this" links spread liberally throughout the site) or that shows drugs, nudity or pornography. It also maintains an extensive "blacklist" of forbidden names that cannot be used to make new profiles, like Batman. Some of this monitoring is quite small beer: you're not allowed to call someone a "jerk" on Facebook if someone reports it. Employees also vigorously enforce their "real-name culture"; they even disabled the actress Lindsay Lohan's account in December after discovering that she was on the site under an alias. ${ }^{120}$

The treatment of negative externalities is only one feature that has influenced the relative fortunes of Friendster, MySpace, and Facebook. However, popular accounts of their downfalls tend to highlight the difficulty that Friendster had in dealing with the Fakester problem and the reputation that MySpace acquired for having a seedy and unsafe community. Decisions on private governance systems contributed to the financial results for these social networks. MySpace was bought by News Corporation in 2005 for $\$ 580$ million and sold in June 2011 for $\$ 35$ million. ${ }^{121}$ Friendster was sold for $\$ 26$ million in 2009 and closed down its original site and deleted user profiles in 2011. ${ }^{122}$ Facebook displaced MySpace as the leading social network measured

117. See Statement of Rights and Responsibilities, Facebook, Apr. 26, 2011, http://www.facebook.com/terms.php.

118. See Nick Summers, Walking the Cyberbeat, THE DAILY BEAST, Apr. 30, 2009, http://www.thedailybeast.com/newsweek/2009/04/30/walking-the-cyberbeat.html.

119. Id.

120. Id.

121. See Jessica E. Vascellaro, Emily Steel \& Russell Adams, News Corp. Sells Myspace for a Song, WALL ST. J., Jun. 30, 2011, available at http://online.wsj.com/article/SB1000142405270 2304584004576415932273770852.html.

122. See Julianne Pepitone, Friendster Plans to Nuke Its User Data, CNN MONEY (Apr. 26, 2011, 2:48 PM), http://money.cnn.com/2011/04/26/technology/friendster/index.htm. 
by users and page views in May 2008. ${ }^{123}$ Facebook's has a market value of almost $\$ 100$ billion based on trading in its stock in private markets. ${ }^{124}$

One of the major business risks that Facebook faces-and a source of continuing controversy-concerns how much control it gives users over the dissemination of private data. ${ }^{125}$ Individual users can face adverse effects from disclosure while other members of the Facebook platform-such as advertisers and application developers-benefit from greater access to data. Its governance rules concerning privacy-related negative externalities, and its choices relative to new competitors like Google+, are likely to be important for striking the optimal balance between the competing interests of members of its community. ${ }^{126}$

\section{B. STOCK EXCHANGES}

Modern stock exchanges-which have detailed rules and regulations that are designed to ensure the integrity of their markets-provide another example of how communities govern negative externalities. As observers note, "[s]tock exchanges around the world invest considerable manpower, technological effort and financial resources to curb market manipulation and to promote market efficiency and integrity."127 They impose rules concerning market manipulation-doing things to artificially affect market signals such as disclosing false information or creating a false impression of trading activity. They also impose rules concerning insider trading-using material non-public information. Nasdaq, for example, has detailed rules "regarding

123. See Caroline McCarthy, Facebook Overtakes MySpace Globally, ZDNET (June 23, 2008, 9:13 AM), http://www.zdnet.com/news/facebook-overtakes-myspace-globally/207724.

124. See Lee Spears \& Mohammed Hadi, Facebook's Implied Value Slips to $\$ 98$ Billion in Private Market Trading, BloOMBERG, Feb. 16, 2012, http://www.bloomberg.com/news/ 2012-02-16/ facebook-s-implied-value-slips-to-98-billion-in-private-market-trading.html.

125. For a litany of controversies surround Facebook, see Criticism of Facebook, WIKPEDIA, http://en.wikipedia.org/wiki/Criticism_of_Facebook (last visited Mar. 1, 2012).

126. There is perhaps no better antidote to professional prognostication than the history of social networks. Friendster was a highly praised internet business for much of 2003 before evolving into a famous case study of business mistakes. See Boyd, supra note 67; Mikolaj Jan Piskorski \& Carin-Isabel Knoop, Friendster (A) (Harvard Business School, Paper No. 9-707409, 2007). MySpace was then lauded for its brilliant effort, in part based on its willingness to let anyone do anything on its site, in displacing Friendster. Commentators thought that it had "won" the race for dominance in social networking. See Marc Gunther, News Corp. (hearts) Myspace, CNNMONEY, Mar. 29, 2006, http://money.cnn.com/2006/03/28/ technology/pluggedin_fortune/. It remains to be seen whether Facebook will make the sorts of mistakes in balancing the interests of its community-in particular juggling negative and positive externalities that upended its predecessors or many other possible business mistakes that could reverse its growth.

127. See Douglas Cumming, Sofia Johan \& Dan Li, Exchange Trading Rules and Stock Market Liquidity, 99 J. OF FIN. ECON. 651 (2011). 
wash trades, pre-arranged trading, fictitious orders, giving up priority, churning, front-running, and a variety of other types of practices." 128 In addition to market manipulation rules, exchanges have rules for business dealings among members including rules about payment and delivery. ${ }^{129}$ Exchanges enforce these rules in a variety of ways including expelling members for violating them. ${ }^{130}$

While modern stock exchanges are subject to government laws and regulation, modern exchanges adopt and enforce their own rules as well. ${ }^{131}$ In the United States, for example, exchanges design their own rules. Although the Securities and Exchange Commission ("SEC") approves rules governing U.S. exchanges, the SEC does not dictate the rules. ${ }^{132}$ In fact, a critical feature in the development of stock exchanges in the eighteenth century was the ability to exclude users for bad behavior as the early history of the London Stock Exchange-described below-demonstrates. Indeed, private control over negative externalities among traders was critical to the emergence of the modern stock exchange.

The securities market in London operated informally for a couple of hundred years. ${ }^{133}$ Securities were traded bilaterally as far back as the sixteenth century. ${ }^{134}$ It was convenient for traders to have places to congregate. They initially did so at the Royal Exchange, where commodities were traded. After being ejected for crowding the exchange, traders aggregated themselves in some of the coffee houses_-such as Jonathan's Coffee House-in the nearby Exchange Alley. ${ }^{135}$

128. See id. at 652 .

129. NYSE Enforcement, NYSE, http://rules.nyse.com/NYSE/Rules/ (last visited Aug. 1, 2011).

130. For the rules governing NYSE enforcement actions, see Disciplinary Rules (Rules 475-77), NYSE, http://rules.nyse.com/nysetools/PlatformViewer.asp?SelectedNode=chp _1_7\&manual $=/$ nyse $/$ rules $/$ nyse-rules $/$. For a list of disciplinary actions by the NYSE, see http://www.nyse.com/DiscAxn/discAxnIndex.html.

131. See John Carson, Self Regulation in Securities Markets: International Trends and New Directions after the Financial Crisis, Compliax Consulting, InC., Mar. 2009, http:/ / compliax.com/app/download/1791228504/Self-Regulation+in+Securities+Markets.pdf.

132. See 15 U.S.C. $\int 78 \mathrm{~s}(\mathrm{~b})(1)$ (2010) (statute empowering self-regulatory organizations, including exchanges, to make their own rules, subject to approval by the SEC); SEC Release 34-50699, Part I.A, Nov. 18, 2004, available at http://www.sec.gov/rules/proposed/3450699.htm (background information on the self-regulation of exchanges, in the context of a proposed rule to strengthen exchange governance).

133. See Ranald Michie, The London Stock Exchange: A History 15 (1999).

134. Id.

135. See Edward Stringham, The Emergence of the London Stock Exchange as a SelfPolicing Club, 17(2) J. Private. ENTERPRISE 1, 4-6 (2002). 
In the early days of the London Stock Exchange, traders faced the problem of ensuring that exchange partners would honor agreements to complete buy and sale orders when they came due. The Barnards Act, passed in 1734, declared time-based bargains a form of gambling for which it was not possible to enforce contracts. ${ }^{136}$ Because traders could not rely on contracts, "[i]t was ... left to the market participants themselves to create a code of conduct that enforced the conditions necessary for trade. Even without the legal impediments ... those who participated actively in the market would seek to find a solution to their own problems among themselves." 137 In the mid eighteenth century, several groups of traders in financial instruments-including bankers and marine underwritersorganized themselves into exclusive associations in which members who violated the stated or unstated rules of the association could be ejected. ${ }^{138}$

A group of stockbrokers, who had operated an informal market at Jonathan's Coffee House, tried to do the same in 1761. According to one contemporary source, "The gentlemen at this very period of time ... . have taken it into their heads that some of the fraternity are not so good as themselves .... and have entered into an association to exclude them from J----'s coffee-house.",139

They paid the coffee house for the right to use the premises exclusively for three hours a day. ${ }^{140}$ As required by that agreement, the master of the coffee house, a Mr. Feres, apparently ejected a Mr. Renoux who then sued for assault. ${ }^{141}$ According to the London Chronicle, on June 9, 1762:

It being proved at the trial that that house had been a market (time out of mind) for buying and selling government securities, the Jury brought in their verdict for the plaintiff, with one shilling damage; by which means Jonathan's Coffee-house is now a free and open market, and all combinations there destroyed. ${ }^{142}$

In 1772, a group of London stockbrokers took another approach towards creating an exclusive trading society. They funded the construction of a new building, the Stock Exchange, for trading. ${ }^{143}$ Given the previous

136. MiCHIE, supra note 133 , at 31 .

137. Id.

138. Id.

139. See C. F. Smith, The Early History of the London Stock Exchange, 19 AMER. ECON. REV. 206, 215 (1929) (quoting T. MORTIMER, EVERY MAN His Own BrOKER, xiv (2d ed. 1761)).

140. See MiCHIE, supra note 133 , at 31.

141. See James Oldham, Law Reporting in the London Newspapers, 1756-1786, 31 AM. J. LEGAL HisT. 177, 185-86 (1987).

142. Id. at 186.

143. See MiCHIE, supra note 133. 
legal result, they made admission open for a daily fee. ${ }^{144}$ By the late 1790 s, with the growth in securities markets, the governing committee of the Stock Exchange found that they did not have enough power to enforce discipline and faced difficulties in funding the administration of the exchange. The owners of the Stock Exchange decided in January 1801 to convert the open exchange into a closed "subscription room" for which members paid an annual fee. ${ }^{145}$ The London Stock Exchange started on March 3, 1801. ${ }^{146}$

The new exchange adopted regulations for conducting business. "[A]dherence to these rules and regulations was monitored and adjudicated by a committee, including full-time administrative staff, and enforced by the threat of expulsion from the market." ${ }^{\text {147 }}$ Most of the regulations focused on creating trust among members, particularly involving payment and delivery. As a late nineteenth century treatise put it:

[The London Stock Exchange's] main objects appear to be the easy and expeditious transaction of business, and the enforcement of fair dealing among its members. To these ends ... a set of results formed for the admission and expulsion of members, and for the control of their conduct both between themselves and towards the public. $^{148}$

The London Stock Exchange was also concerned with limiting negative externalities that members could impose on each other through market manipulation or asymmetric information. Writing about events in 1943, one historian observes, "[o]ne of the main functions of the Stock Exchange was to ensure a level playing field for all its members in terms of equal access to information. Consequently ... it tried to ensure that price-sensitive information, such as company results, were released simultaneously to all."149 The Exchange also "treated very seriously any matter of insider trading, whether accidental or deliberate." ${ }^{150}$ In 1943, it expelled one member who received tips from a journalist on his stock recommendations. ${ }^{151}$ It also warned members about doing business with non-members who raised

144. Id.

145. Id. at 35 .

146. Id.

147. Id.

148. See Rudolph Eyre Melsheimer \& Walter Laurence, The LaW AND Customs of THE LONDON STOCK EXCHANGE 1 (Nabu 1879).

149. MiCHIE, supra note 133, at 294-95.

150. Id. at 295 .

151. Id. 
insider-trading concerns. At least at this time, the government had no interest in outlawing insider trading. ${ }^{152}$

Stock exchanges-like other platforms-have incentives to deal with negative externalities among their members and to maintain the reputation of the exchange with the public. That does not necessarily mean that they have adopted the socially optimal governance structure. And governments, especially after the Great Depression, have imposed regulations on stock exchanges and also oversee the rules these exchanges adopt themselves.

There is a long-standing debate on the efficacy of government regulation that is beyond the scope of this Article. ${ }^{153}$ The analysis of governance mechanisms for multi-sided platforms indicates, however, that stock exchanges have incentives to adopt rules and regulations to maximize the value of the platform and to do so in part by mitigating negative externalities among their members. The analysis of government intervention in securities markets should consider whether the government could provide tools that would help private enforcement, whether there are aspects of private regulation that could be done more efficiently by the government, and whether there are deviations between private and public incentives for maximizing the value of the platform.

\section{SEARCh ENGINeS}

Search engines also provide a clear example of how multi-sided platforms privately govern negative externalities - and in particular how search engines regulate the problem of companies manipulating search rankings. Strong financial incentives exist for companies to rank as highly as possible in search engine results. For example, a media website makes more money if it attracts more viewers because advertising revenue is proportional to viewers and because the website will attract more viewers if it ranks more highly. Likewise, an e-commerce website makes more money if it attracts more viewers. Because some fraction of viewers will buy products and services from the website, the more viewers the website has the more sales it will make.

Companies that run websites can make more money if they can use knowledge of a search engine's algorithm to-in effect-trick the search

152. $I d$. at 296 .

153. For an important contribution to the literature, see Rafael La Porta, Florencio Lopez-de-Silanes \& Andrei Shleifer, What Works in Securities Laws?, 61 J. OF FIN. 1 (2006). They conclude from a study of securities markets in forty-nine countries that laws facilitating private enforcement through disclosure and liability rules benefit stock markets and that public enforcement plays a modest role at best. Id. at 20 . 
engine into thinking their websites rank higher than they should. According to one study, the top spot in a search ranking gets more than a third of the clicks compared to about seventeen percent for the second spot and three percent for the tenth spot. ${ }^{154}$ More clicks results in more viewers.

However, opportunistic behavior associated with the manipulation of search results imposes significant costs on users. First, users receive distorted and inaccurate search results. Second, strategies that manipulate search rankings degrade the value of search results since users have no way of knowing whether any particular search result is the product of a manipulated or an unmanipulated ranking. The search engines deploy counterstrategiesincluding frequent changes in the algorithms as well as governance rules-to counter efforts at manipulating. ${ }^{155}$

Google's ongoing efforts to detect and punish websites that manipulate the Google search algorithm illustrate the role of governance rules for search engines. Google has developed a sophisticated governance system for mitigating negative externalities for its platform community of users, websites, and advertisers. However, it faces some difficult tradeoffs. It has developed guidelines that describe the good activities that it encourages websites to engage in and the bad activities that are banned because they distort the information-value of results. ${ }^{156}$ It provides recommendations to webmasters on good technical, design, and content practices that will benefit website users and also help the website signal to the search algorithm that it is a high quality and relevant site. ${ }^{157}$ This is an example of trying to promote positive externalities.

Google also describes deceptive and manipulative practices that could result in the imposition of sanctions on the offending website. ${ }^{158}$ The basic principle is that websites are not supposed to do things that are designed to influence the search engine results as opposed to providing value to users. Google identifies specific techniques that websites are not supposed to use, including having hidden text or links, cloaking or sneaky redirects, loading pages with irrelevant keywords, having multiple pages with substantially the same content, and using doorway pages that are just created for search

154. Daniel Ruby, The Value of Google Result Positioning, Insights, CHITIKA (May 25, 2010), http:/ /insights.chitika.com/2010/the-value-of-google-result-positioning.

155. See Webmaster Tools: Search Engine Optimization (SEO), Google, http:/ / support.google.com/webmasters/bin/answer.py?hl=en\&answer $=35291 \& \mathrm{ctx}=\mathrm{cb} \& \mathrm{sr}$ $\mathrm{c}=\mathrm{cb} \& \mathrm{cbid}=\mathrm{mi} 5 \mathrm{abtuzaoia}$ (last visited Apr. 17, 2012).

156. See id.

157. See id.

158. See id. 
engines. ${ }^{159}$ The list is not intended to be exhaustive, and Google makes it clear that it will take action for any effort to distort search results artificially. ${ }^{160}$

These quality guidelines cover the most common forms of deceptive or manipulative behavior, but Google may respond negatively to other misleading practices not listed here (e.g. tricking users by registering misspellings of well-known websites). It's not safe to assume that just because a specific deceptive technique isn't included on this page, Google approves of it. Webmasters who spend their energies upholding the spirit of the basic principles will provide a much better user experience and subsequently enjoy better ranking than those who spend their time looking for loopholes they can exploit. ${ }^{161}$

Google cannot disclose too much about how it detects violations because that would enable websites to manipulate the system. ${ }^{162}$

For example, Google imposed sanctions on J.C. Penney-an American department store chain that also sells merchandise online-for manipulating search results. In late 2010, the company achieved the top search result rankings for many of the products that it sells as a result of a highly successful Search Engine Optimization ("SEO") strategy. ${ }^{163}$ An SEO consultant for the company inserted terms for J.C. Penney products in thousands of websites along with links back to www.jcpenney.com. ${ }^{164} \mathrm{By}$ doing this, the SEO consultant fooled Google's search algorithm into thinking that www.jcpenney.com was a more relevant website for the

159. According to Google, "[d]oorway pages are typically large sets of poor-quality pages where each page is optimized for a specific keyword or phrase. In many cases, doorway pages are written to rank for a particular phrase and then funnel users to a single destination." Webmaster Tools: Cloaking, sneaky Javascript redirects, and doorway pages, GOOGLE, http://www.google.com/support/webmasters/bin/answer.py?answer=66355 (last visited Mar. 1, 2012).

160. See Webmaster Tools: Search Engine Optimization, supra note 133.

161. See Webmaster Tools: Webmaster Guidelines, GOOGLE, http://support.google.com/ webmasters $/$ bin $/$ answer.py?hl=en\&answer $=35769 \&$ topic $=2370419 \& \mathrm{ctx}=$ topic (last visited Mar. 19, 2012).

162. The New York Times quotes the editor of the Search Engine Land blog, which covers the search industry: " 'Google is just cagey about everything.' That, he said, is because the company is perpetually worried that the more it reveals about the vaunted mathematical algorithm it uses to drive search results, the more people will try to game it." David Segal, $A$ Bully Finds a Pulpit on the Web, N.Y. TIMES, Nov. 28, 2010, at BU1, available at http://www.nytimes.com/2010/11/28/business/28borker.html?pagewanted=all. A spammers' forum, www.blackhatworld.com, even provides tips for gaming the rules.

163. See David Segal, The Dirty Little Secrets of Search, N.Y. TimES, Feb. 13, 2011, at BU1, available at http://www.nytimes.com/2011/02/13/business/13search.html?pagewanted=all.

164. Id. 
inserted search terms than it really was. When it found out about J.C. Penney's strategy, Google imposed a penalty on the company. It manually reduced the search rankings for J.C. Penney for approximately 90 days. ${ }^{165}$ As a result of the manual action J.C. Penney's rankings fell. For the search term "Samsonite carry on luggage," for instance, J.C. Penny fell from the first to the seventy-first spot. ${ }^{166}$ Given the low click rate after the tenth spot on the first page, downgrading J.C. Penney to the seventy-first spot had almost the same effect as excluding it from that particular search query result altogether.

Google's governance system balances the value of providing users access to websites, ensuring the accuracy of the rankings, and deterring websites from manipulating the system. ${ }^{167}$ In some cases it appears that Google subjects websites to manual actions that reduce their rankings for some period of time. ${ }^{168}$ In other cases_like the case of J.C. Penney-websites are subjected to manual actions that reduce their rankings until they apply for reconsideration. Still in other cases websites are delisted altogether, although they have the possibility of applying for reconsideration. For example, BMW.de was delisted in 2006 for using doorway pages. ${ }^{169}$

Google's manual process involves the use of algorithms to detect possible violations as well as human decisions on how to respond and whether to reconsider. As the web has expanded, however, it is not feasible for Google to rely mainly on this process to ensure the quality of website rankings and mitigate externalities. As of June 2011, more than 350 million websites existed and about 150,000 new websites appeared each day. ${ }^{170}$ Consequently, Google modifies its search algorithm frequently both to improve its performance and to counter efforts to game the algorithm. Changes in the algorithm result in changes in rankings and in some cases material changes in rankings. For example, a major change to the algorithm in February 2011 affected the quality score (an estimate of the relevance of a

165. See Matt Rosoff, Google Has Stopped Punishing JC Penney, Bus. InsIDER, May 25, 2011, http://articles.businessinsider.com/2011-05-25/tech/30017965_1_panda-google-jc-penney.

166. See Segal, supra note 163.

167. For further discussions of practices that Google has attacked, see Barry Schwartz, Google Vows Renewed Look At Cloaking in 2011, SEARCH ENGINE LAND, Dec. 28, 2010, http:// searchengineland.com/google-vows-to-look-at-deceptive-cloaking-techniques-59802.

168. See Mitch Fournier, What a Google Penalty Looks Like, MiTCH FOURNIER (July 21, 2011), http:/ / mitchfournier.com/2011/07/21/what-a-google-penalty-looks-like.

169. See Tom Espiner, Google Blacklists BMW.de, CNET NEWs (Feb. 6, 2006, 6:58 AM), http:// news.cnet.com/Google-blacklists-BMW.de/2100-1024_3-6035412.html?tag=content Main;contentBody;1n.

170. See Julie O’Dell, How Big Is The Web \& How Fast Is It Growing?, Mashable (Jun. 19, 2011), http://mashable.com/2011/06/19/how-many-websites/\#17199How-Big-Is-the-Web. 
website to a keyword) of 11.8 percent of the queries that Google received. ${ }^{171}$ As a cross check on the changes to the algorithm, Google looked at whether its changes had detected websites that users (based on Chrome browser users) had chosen to block. The changes eliminated eighty-four percent of the several dozen most-blocked domains. ${ }^{172}$

Changes in the algorithm are-in the short run-a zero-sum game for websites. Some websites rise in the rankings while others fall. Those that rise in the rankings quietly celebrate while some of those who fall complain loudly. Those who complain do not necessarily have strong grounds. For instance, some of the websites that fall in the rankings do so because they have tried to manipulate the algorithm and have been penalized by Google as a consequence. Other websites fall in the rankings as collateral damage from the attempts by some websites to artificially inflate their rankings. In dealing with attempts to manipulate search rankings, Google is forced to repeatedly change its algorithm in ways that may create uncertainty even for websites that play by the rules. In other words, if all websites played by the rules they would all have greater certainty about the ranking algorithm.

Google's efforts to deal with negative externalities generated by opportunistic websites rest entirely on its ability to exercise property rights over the platform. By delisting websites, Google preserves the quality of its rankings and provides a significant disincentive to websites engaging in manipulation of search results. Google achieves almost the same result by manually reducing website rankings since there is a low value to being listed far down in the rankings. And finally, by being able to change its algorithm, Google possesses a scalable approach for mitigating negative externalities on a massively large and exponentially expanding platform. The consequence is that, over the longer run, the short run zero-sum game becomes a significant positive-sum gain for the platform, its users, and also for websites, who benefit from the enhanced quality signals that the platform-here Googleis able to provide.

Although Google's private governance regime may be beneficial, it is also controversial. As a result of changes in Google's rankings, several

171. See Finding More High-quality Sites in Search, THE OfFiCiAl GOOGLE Blog (Feb. 24, 2011, 6:50 PM), http://googleblog.blogspot.com/2011/02/finding-more-high-quality-sitesin.html.

172. The changes in part increased the detection of "scraper sites" and "content farms" that present shallow or low quality content by, for example, simply copying snippets from websites that present the original content. See Danny Sullivan, Google Forecloses On Content Farms with "Panda" Algorithm Update, SEARCH ENGINE LAND (Feb. 24, 2011), http:/ / searchengineland.com/google-forecloses-on-content-farms-with-farmer-algorithmupdate-66071. 
companies have filed antitrust suits against Google for allegedly engaging in exclusionary practices or have encouraged governments to initiate antitrust investigations. ${ }^{173}$ There have also been calls for government search neutrality regulation $^{174}$ under which search engines like Google would face legal constraints on adjusting results or penalizing websites. This topic is addressed further in the next Part, which looks at the distinction between efforts to use exclusion to police negative externalities and efforts to use exclusion to restrict competition.

\section{PRIVATE VS. PUBLIC GOVERNANCE IN THE REGULATION OF BAD BEHAVIOR ON PLATFORMS}

Governments have developed extensive responses to bad behavior by members of the community. Criminal law and the police powers of the state deal with various actions by members of society that harm others. Governments use these laws to prohibit practices ranging from fraud to insider trading to murder. Common law also helps regulate negative externalities in the community through property rights, contract rights, and tort liability, which provides incentives to exercise care. Law and economics scholars have argued that much of criminal and common law can be interpreted as a rational attempt to maximize social welfare. ${ }^{175}$

173. See TradeComet.com LLC v. Google, Inc., 693 F. Supp. 2d 370 (S.D.N.Y. 2010); Person v. Google, Inc., No. C 06-7297, 2007 WL 1831111 (N.D. Cal. June 25, 2007); KinderStart.com v. Google, Inc., No. C 06-2057, 2007 WL 831806 (N.D. Cal. Mar. 16, 2007); Google, Inc. v. My'Triggers.com, Inc., No. 09CVH10-14836 (Franklin Cnty. Ct. of Common Pleas, Ohio, Aug. 31, 2011); Leo Condrowicz, The E.U. Probe: Is Google Rigging Its Search Results?, TIME (Dec. 2, 2010), http://www.time.com/time/business/article/ 0,8599,2034138,00.html; Miguel Helft, Lawsuit Says Google Was Unfair to Rival Site, N.Y. Times, Feb. 17, 2009, available at http://www.nytimes.com/2009/02/18/technology/ internet/18google.html; Claire Cain Miller, Texas Probes Google on Ranking of Search Results, N.Y. TIMES, Sept. 4, 2010, at B3, available at http://www.nytimes.com/2010/09/04/ technology/04google.html?adxnnl=1\&adxnnlx=1314113487-4SfkO0V/SuFxNfcRMdHkbQ; Companies Ask EU Commission to Step in on Google Search Ranking Complaint, ITPROPORTAL (Feb. 24, 2010), http://www.itproportal.com/2010/02/24/companies-ask-eu-commissionstep-google-search-ranking-complaint/; Kinderstart Sues Google Over Lower Page Ranking, USA TODAY, Mar. 19, 2006, available at http://www.usatoday.com/tech/news/2006-03-19google-kinderstart_x.htm.

174. See Adam Raff, Search, But You May Not Find, N.Y. Times, Dec. 28, 2009, at A27, available at http://www.nytimes.com/2009/12/28/opinion/28raff.html. The author is the founder of a company that complained to the European Commission that Google's penalties for his site, Foundem, violated the EU's competition laws. See also James Grimmelmann,

Some Skepticism About Search Neutrality, in Adam Marcus, The Next Digital Decade: ESSAYS ON THE FUTURE OF THE INTERNET 435 (Berin Szoka, eds, 2010).

175. See Richard A. Posner, ECONOMiC ANALYSis of LAW 375-380 (4th ed. 1992). 
In addition to criminal law and common law, governments have also adopted regulatory laws to deal with various actions that were not addressed sufficiently by common law. These range from the regulation of pollution, to lemon laws for the sale of used automobiles, to laws against cyber harassment. Many of these laws and regulations have been rationalized along the lines of modern welfare economics as solutions to market failures. ${ }^{176}$

The governance mechanisms for private multi-sided platforms mirror many of these laws and regulations. Multi-sided platforms have developed rules and enforcement mechanisms for dealing with negative externalities created by agents on their platforms. ${ }^{177}$ These include efforts to keep platforms safe from sexual predators, cyber harassment, pornography, underprovision of information, market manipulation, fraud, misrepresentation, and opportunistic distortion of information. ${ }^{178}$ Efforts to police platforms likely provide enormous social value, since some multi-sided platforms would provide significantly poorer service and perhaps not even be viable in the absence of efforts to control negative externalities.

The governance of negative externalities by multi-sided platforms nevertheless raises two public policy issues-anti-competitive exclusion and the benefits of private versus public regulation. Both issues result from the exercise of bouncer's rights to enforce rules to mitigate putative negative externalities. As previously explained, in the early days of the London Stock Exchange English courts prohibited the traders who rented the premises of Jonathan's Coffee House from excluding other traders. ${ }^{179}$ However, the issue of exclusion is increasingly prominent as a result of several multi-sided platforms having created highly successful global businesses. These include Apple, eBay, Facebook, Google, Microsoft, NYSE/Euronext, and Visa.

\section{A. The benefits of Private Regulation}

An important question is whether privately owned multi-sided platforms should be allowed to operate private governance systems that include fines, exile, and jail-like punishment. ${ }^{180}$ Facebook, for example, is regulating social

176. See W. Kip Viscusi, Joseph E. Harrington, JR. \& JOHn M. Vernon, ECONOMICS OF REGULATION AND ANTITRUST 13 (4th ed. 2005).

177. See supra Part V.

178. Id.

179. See supra Section V.B.

180. Google's policy of taking websites that have violated their policy far down in the rankings is sometimes referred to as "Google jail." See Dave Johnson, SEO Dirty Tricks That Can Land Your Company's Website in Google Jail, CBS NEWS (Feb. 28, 2011), http://www.cbsnews.com/8301-505143_162-28650615/seo-dirty-tricks-that-can-land-yourcompanys-website-in-google-jail. 
behavior for a community that has a population that is twice as large as the population of the United States. Should Facebook - a private enterprise-be regulating the pictures that users show to their friends or what users can say to each other?

This question highlights the tradeoff between public and private control because both mechanisms are imperfect. ${ }^{181}$ On the one hand, public control is subject to a myriad of breakdowns in political and legislative processes, imperfections in the government institutions, and unintended consequences of rigid methods of control mandated by law. On the other hand, private control is problematic because for-profit firms-including multi-sided platforms - do not necessarily have incentives to maximize social welfare and may in fact have incentives to reduce social welfare. ${ }^{182}$ As discussed below, a platform could even adopt rules as a pretext to exclude competitors.

Although for-profit firms do not necessarily have incentives to increase social welfare, multi-sided platforms have incentives to maximize the value of their platforms to the community because they obtain profit by extracting value from the platform. They also have incentives to reduce negative externalities. The review of multi-sided platforms above shows that many platforms have-in fact-erected sophisticated governance mechanisms to do so.

In assessing whether public or private control should govern multi-sided platforms, it is important to note that multi-sided platforms have several advantages over public regulators. They have more information on practices that may lead to negative externalities and the impact on the community. As private firms, multi-sided platforms can make decisions quickly on how to deal with negative externalities and modify practices quickly, especially if they observe unintended consequences. They also face fewer constraints-for better or worse-since they are not subject to due process or administrative procedure requirements. However, the platforms lack some of the investigative methods and penalties that a public enforcer would have.

The issue of public versus private control has recently come up in proposals for search neutrality. ${ }^{183}$ Proponents of search neutrality proposals

181. See Simeon Djankov et al., The New Comparative Economics, 31 J. COMPAR. Econ. 595, 598 (2003).

182. See Alexander White \& E. Glen Weyl, Insulated Platform Competition (NET Inst., Working Paper No. 10-17, 2011).

183. See Making the Case for Search Neutrality, SEARCH NEUTRALITY, http://www.searchneutrality.org/search-neutrality (Oct. 11, 2009); Can Search Discrimination by a Monopolist Violate U.S. Antitrust Laws?, FAIRSEARCH, http://www.fairsearch.org/wpcontent/uploads /2011/07 / Can-Search-Discrimination-by-a-Monopolist-Violate-U.S.Antitrust-Laws1.pdf (last visited Apr. 10, 2012). 
argue that the government should prohibit search engines from "manipulating" search results and that all search results should be presented based on a governmentally determined notion of relevance. These proposals are-not surprisingly_-being advanced by websites that have had changes in their rankings as a result of manual downgrading or algorithmic changes. ${ }^{184}$ Such proposals would limit multi-sided platforms' use of bouncer's rights to penalize websites that are trying to manipulate search rankings. These regulations would also limit search engine innovations to improve algorithms, because anyone whose rankings change could claim that the algorithm did not change neutrally. Thus government regulation could impose substantial social costs both by requiring potentially slow and expensive regulatory review and by making false-positive findings of "manipulation" based on differences in complex and potentially subjective judgments of "relevance."185

\section{B. Anti-COMPetitive Exclusion: A Proposed Three-SteP ANALYSIS}

When a firm is excluded from participating in a multi-sided platform it can incur significant harm. The excluded firm may decide to sue under antitrust laws and argue that the multi-sided platform uses significant market power to harm competition by excluding the firm from a relevant antitrust market. The court or competition authority will then need to decide whether the exclusion is anti-competitive or an efficient business response by the multi-sided platform. The multi-sided platform may explain that it has established efficient rules for reducing negative externalities and that it excluded the firm because the firm violated the rules the platform. That argument could be true as shown above, or it could be a pretext for anticompetitive exclusion. This article proposes a three-part test to help courts and competition authorities distinguish between efficient private governance and anti-competitive exclusion.

When a firm-especially one with significant market power-excludes another firm from the market, its actions may be subject to scrutiny under antitrust laws. ${ }^{186}$ In the United States, exclusionary practices may violate Section 2 of the Sherman Act, which prohibits attempts to create or maintain

184. See Adam Raff, Search, But You May Not Find, N.Y. Times, Dec. 27, 2009, available at http://www.nytimes.com/2009/12/28/opinion/28raff.html.

185. See James Grimmelmann, Some Skepticism About Search Neutrality, in THE NEXT Digital DeCade: Essays on the Future of THE InTERnet (Berin Szoka \& Adam Marcus eds., 2010).

186. See Einer Elhauge \& Damien Geradin, Global Antitrust Law And ECONOMICS (Foundation 2d ed. 2011). 
a monopoly. In certain circumstances, exclusionary practices may also violate Section 1, which prohibits unreasonable agreements in restraint of trade. ${ }^{187}$ In the European Union, exclusionary practices could be considered abuses of dominance under the Article 102 TFEU. ${ }^{188}$

As antitrust has adopted a more economics-based approach, some aspects of exclusionary abuse claims have been viewed as problematic or at least controversial. ${ }^{189}$ For example, U.S. courts have expressed skepticism over vertical restraint cases and monopoly leveraging. ${ }^{190}$ Courts have generally rejected claims premised on the exclusion of a competitor from access to property owned by the defendant. ${ }^{191}$ U.S. courts have also expressed skepticism over claims involving the exclusion of direct competitors such as those that stem from the improvement of a product. ${ }^{192}$ In fact, they have raised the bar for some practices sufficiently high that they are effectively (if not literally) per se legal under the rule of reason. For example, it is extremely difficult for a plaintiff to establish that a rival has engaged in "predatory pricing"- that is the rival has "priced low" to drive out a rival and thereby monopolize a market. ${ }^{193}$

The European Union has also moved in this direction. The European Commission guidelines on enforcement priorities for Article 82 (now Article 102 TFEU) recognize that vertical and horizontal exclusionary practices should be subject to the rule of reason and that depending on the factual circumstances a firm with significant market power may not have the ability or incentives to foreclose a rival. ${ }^{194}$ The European Union continues to

187. See Sherman Antitrust Act, 15 U.S.C. \$S 1-2 (1890).

188. See Treaty on the Functioning of the European Union, art. 102, May 9, 2008, 51 OFFICIAL J. OF EUR. UNION 89 (2008).

189. The U.S. courts in particular have been influenced by the findings of economists that firms engage in vertical foreclosure practices for pro-competitive reasons. See Leegin Creative Leather Prods., Inc v. PSKS, Inc., 551 U.S 877 (2007); Brief for Economists as Amici Curiae Supporting Petitioner, Leegin Creative Leather Prods., Inc. v. PSKS, Inc., 551 U.S. 877 (2007).

190. See Herbert Hovenkamp \& Phillip E. Areeda, Fundamentals of ANTITRUST LAW (Aspen 3rd ed. 2004); ElHAUgE \& GERADIN, supra note 186.

191. See Verizon Communications Inc. v. Law Offices of Curtis V. Trinko, LLP, 540 U.S 398 (2003).

192. See Allied Orthopedic Appliances Inc., v. Tyco Health Care Group LP, 592 F.3d 991 (9th Cir. 2010).

193. Mark S. Popofsky, Defining Exclusionary Conduct: Section 2, The Rule of Reason, and the Unifying Principle Underlying Antitrust Rules, 73 ANTITRUST L. J. 435, 442-43 (2006).

194. See European Commission, Communication from the Commission-Guidance on Its Enforcement Priorities in Applying Article 82 (EC) to Abusive Exclusionary Conduct by Dominant Undertaking (Feb. 24, 2009), available at http://eur-lex.europa.eu/LexUriServ/ LexUriServ.do?uri=CELEX:52009XC0224(01):EN:NOT. See also Steven C. Sunshine, 
mandate access to essential facilities but imposes a significant burden of persuasion on the parties demanding access. ${ }^{195}$

Nevertheless, it is possible that firms with significant market power may engage in anti-competitive exclusion. The question addressed here is how to handle exclusionary conduct cases that result from the imposition of penalties on firms under established multi-sided platform governance systems.

A platform could invoke negative externalities in excluding a possible rival from access to its platform. If it does not have a governance system in operation, and exclusion of the competitor is based on an idiosyncratic decision rather than a systematic process for dealing with negative externalities, there is no reason-based on the analysis above-to evaluate the conduct differently than other exclusionary conduct allegations. The court should take the efficiency explanation offered by the defendant into account in weighing the pro-competitive and anti-competitive aspects of the practice, or in applying the otherwise applicable legal framework. ${ }^{196}$

It is now widely accepted that antitrust rules should take into account the costs and likelihood of making mistakes. ${ }^{197}$ Rules that tend to absolve firms that have engaged in anti-competitive practices can encourage more firms to engage in these practices. Rules that tend to condemn firms for engaging in practices that are pro-competitive can deter firms from advancing social welfare.

That balance between false positives and false negatives is especially critical when the challenged action of the platform is taken pursuant to a preexisting governance system. The fact that a firm is a platform and maintains a governance system for dealing with negative externalities provides a strong presumption that the firm is increasing social welfare by policing bad behavior pursuant to that governance system on its platform. That is likely to

Deputy Assistant Attorney General, U.S. Dep't of Justice, Address at the American Bar Association Section of Antitrust Law: Vertical Merger Enforcement Policy (Apr. 5. 1995), available at http://www.justice.gov/atr/public/speeches/2215.pdf.

195. See Case C-7/97, Oscar Bronner GmbH \& Co. KG v. Mediaprint Zeitungs, 1998 E.C.R. I-7791, \$ $41-47$ (holding that refusing access does not constitute abuse of a dominant position within the meaning of Article 86 of TFEU, even when there is only one nationwide newspaper home-delivery scheme, and even when the small circulation of rival newspapers renders it economically impossible to establish similar delivery schemes).

196. See the five part test in United States v. Microsoft, 253 F.3d 34 (D.C. Cir. 2001).

197. See Elhauge \& Geradin, supra note 186; Herbert Hovenkamp \& Phillip E. Areeda, Fundamentals of Antitrust Law (Aspen 3d ed. 2004); David S. Evans, Why Different Jurisdictions Do Not (and Should Not) Adopt the Same Antitrust Rules, 10 CHI. J. INTL. L. 161 (2009); Frederick Beckner III \& Steven C. Salop, Decision Theory and Antitrust Rules, 67 ANTITRUST L. J. 41 (1999-2000). 
be an extremely valuable service to the consumers on the various sides of the platform. The ability to exclude those who create negative externalities is critical to the functioning of that governance system and ultimately for the overall value of the platform.

Of course, it is possible that a platform has established or structured a governance system as a pretext for excluding competitors. A platform could establish rules that prohibit participants from relying on or interconnecting with other platforms. Prior to its break-up_for example-AT\&T provided local and long-distance telephone service under public utility rate regulation and also had an unregulated equipment manufacturer. ${ }^{198}$ It established rules concerning the interconnection of equipment and other services to its networks that it claimed were designed to ensure the integrity of the telephone system. ${ }^{199}$ It has been argued that AT\&T sometimes applied these rules to exclude competing equipment manufacturers and competing longdistance telephone service providers in violation of the antitrust laws. ${ }^{200}$ To settle an antitrust case brought by the U.S. Department of Justice, AT\&T agreed to divest its local operating companies and its equipment manufacturer. ${ }^{201}$ Therefore, the existence of a governance system should not-by itself - preclude a finding of anti-competitive exclusion.

Nevertheless, the existence of a governance system increases the likelihood that the practice that results in exclusion is pro-competitive. Governance systems are common among platforms, are necessary for dealing with negative externalities, and can increase consumer welfare. To the extent there are serious negative externality problems on the platform, antitrust decisions that prohibit firms from engaging in pro-competitive exclusion would impose significant costs on the platform because the platform would be forced to weaken its enforcement mechanisms. Moreover, other platforms concerned with the risk of an antitrust suit will weaken their government systems to the overall detriment of platform customers.

The 1762 decision concerning Jonathan's Coffee House ${ }^{202}$ illustrates the dangers of limiting the ability of private platforms to exercise bouncer's rights to regulate their platforms. As a result of the decision, the first London Stock Exchange had to adopt ineffective methods for dealing with negative externalities among members. It was not until forty years after the decision

198. See Tim Wu, The Master Switch: The Rise and Fall of Information EMPIRES 57, 188-89 (2010).

199. Id. at 189 .

200. Id. at 108-09.

201. United States v. Western Elec. Co. Inc., 969 F.2d 1231 (D.C. Cir. 1992).

202. Oldham, supra note 141 , at $185-86$. 
that the English stock exchange could effectively regulate bad behavior among its members. ${ }^{203}$ The error-cost analysis of governance systems indicates that the standard rule of reason approach should be modified in the same way-and for similar reasons - it has been modified for other practices that are likely to be pro-competitive. ${ }^{204}$ There should be a presumption that exclusion that results from an established governance system for dealing with negative externalities is pro-competitive. The plaintiff should bear the burden of persuasion of showing otherwise.

\section{Figure 1}

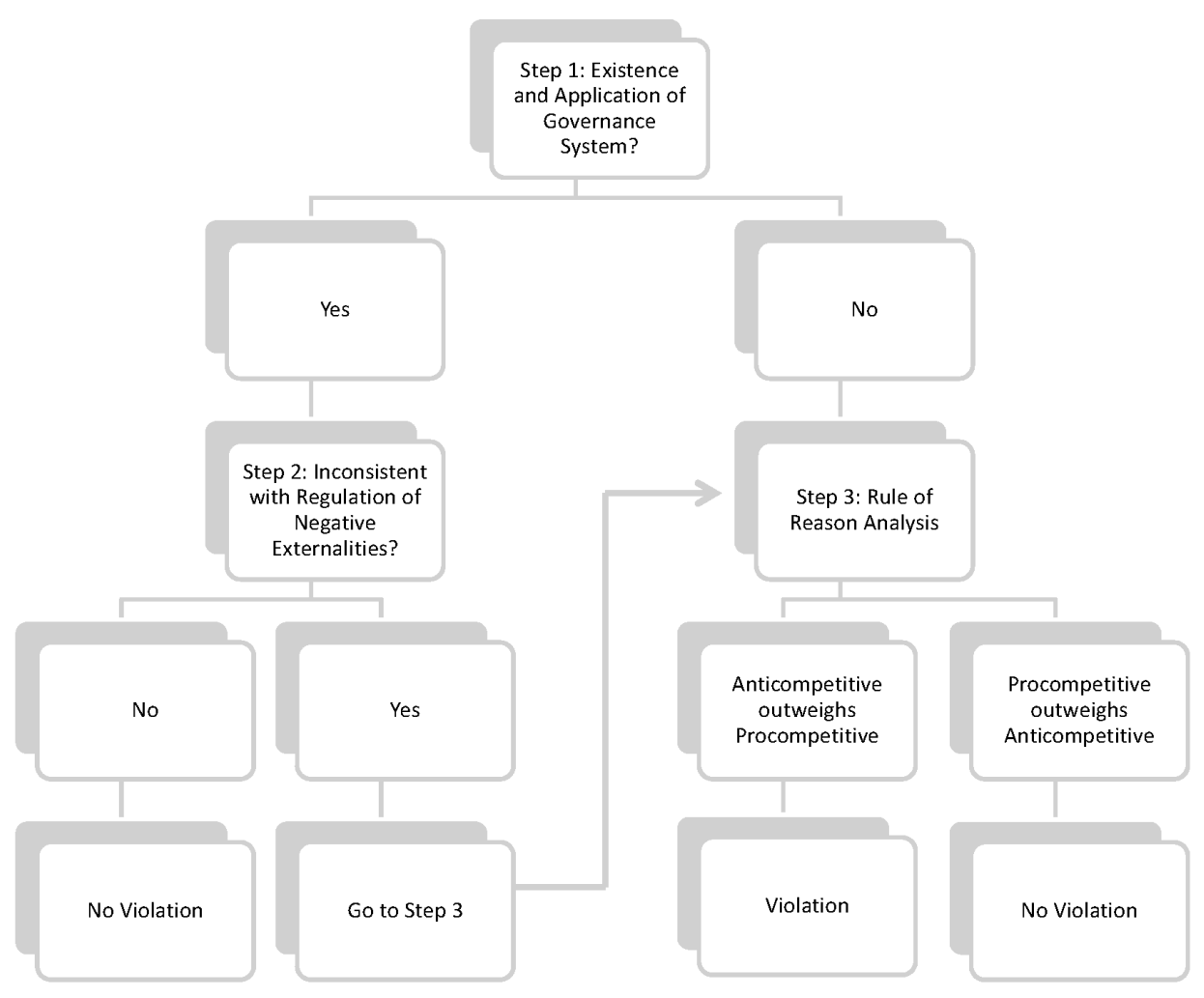

Based on these considerations this Article proposes a three-step testsummarized in Figure 1-for exclusionary behavior involving multi-sided platforms. This Article assumes the plaintiff has already met the usual burden

203. MiCHIE, supra note 133 , at 35.

204. See David S. Evans \& A. Jorge Padilla, Designing Antitrust Rules for Assessing Unilateral Practices: A Neo-Chicago Approach, 72 U. CHI. L. REV 72 (2005). In this Article, I am focusing only on how existing antitrust rules should be modified given the existence of platformbased governance systems for dealing with negative externalities. I do not address whether existing rules are sound. 
of establishing a relevant market and-as applicable - the potential for the challenged practice to raise price or restrict output. In the first step of the analysis-defending against the complainant's prima facie case-the platform should have the opportunity to demonstrate that it has established a governance system for dealing with negative externalities and that the practice at issue results from the exercise of that governance system. If the platform cannot do so, standard antitrust rules applicable to the practice at issue should apply (see step three). If the platform can do so, the analysis should move to the second step.

The second step should consider whether the exclusion is inconsistent with the use of the governance system to deal with negative externalities or whether the governance system itself has been established as a pretext for excluding competitors. The plaintiff should bear the burden of demonstrating that the governance system is not reasonably related to enforcement of the goals the governance mechanism is designed to achieve. The plaintiff may be able to show that the platform applied the rules differentially_excluding a competitor when it would not have ordinarily excluded the firm that allegedly violated the rules — or created a separate class of offenses that results in the exclusion of competitors. The plaintiff may also be able to show that the governance system is unrelated to the correction of negative externalities or established as a pretext for exclusion. The plaintiff's claim should be rejected unless the plaintiff can demonstrate that the practice is inconsistent with the mitigation of negative externalities. Otherwise the analysis should proceed to the third step.

The third step-arrived at if the defendant fails the first step or the plaintiff succeeds in the second step-would follow the standard antitrust analysis applicable to the challenged conduct at issue. In the United States, the third step would involve analyzing whether the practice (i) forecloses or raises rivals' costs in a manner that enhances the defendant's ability to raise price or restrict market output to the detriment of consumers and then (ii) weighing the anti-competitive and pro-competitive effects to determine whether the practice is, on net, anti-competitive. Under many circumstances, a successful showing by the complainant under step two would demonstrate the lack of pro-competitive effects.

As with any error-cost based approach, this three-step analysis cannot eliminate false positives and false negatives. The plaintiff might succeed in showing that the application of an exclusionary penalty is a pretext even though it is a valid attempt to eliminate a negative externality. A defendant might succeed in showing that an exclusionary penalty is part of a procompetitive governance system when in fact it is designed to exclude a competitor and harm consumers. Nevertheless, the approach reduces the 
likelihood and costs of errors in light of the role of governance systems in reducing negative externalities that would otherwise harm consumers.

\section{CONCLUSION}

Although the business model has been around for millennia, multi-sided platforms have become particularly prominent since the advent of the commercial web. ${ }^{205}$ The Internet and web technologies facilitate the creation of platforms for different types of users that would benefit from getting together. ${ }^{206}$ As a result of scale economies and the ability to either replicate a platform across geographies, or to connect global communities, some of these platforms have become global players. These multi-sided platforms are likely to attract increasing attention from policymakers because of their economic and social significance. Several already have.

An essential feature of these platforms is that they promote positive externalities between members of the community. But as with any community, there are numerous opportunities for people and businesses to generate negative externalities that can reduce economic efficiency and-in the extreme-lead to the tragedy of the commons.

Most discussions of these platforms have focused on how multi-sided platforms create value by harnessing positive externalities and how positive network effects can result in the emergence of dominant platforms in particular categories. Much less attention has been given to the role these platforms play in mitigating negative externalities. As it turns out, many of these platforms have developed governance systems for dealing with bad behavior. These governance systems ultimately depend on the ability of the platform to exclude agents from some quantum of the platform, including prohibiting them from the platform entirely.

Exercising these exclusionary rights is controversial. The platform has to balance the interests of its multiple constituents. Rules concerning negative externalities-just as those involving positive ones—shift value between different sides. Like a polity, a platform must balance competing values, such as freedom of speech and protection from hate speech and other verbal harassment. The exercise of exclusionary rights to enforce rules can also lead to complaints by the excluded parties and in some cases lawsuits. The fact that a platform is engaging in exclusion as part of a governance system for dealing with negative externalities has important implications for the antitrust analysis of exclusion. "Exclusion" of actors who diminish the value of the

205. See Evans \& Schmalensee, supra note 7, at 152.

206. See Evans \& Schmalensee, supra note 5, at 5. 
platform to all its constituents is prevalent, important, and beneficial. Antitrust analysis should therefore use exclusion based on a governance system for dealing with negative externalities as a shield for practices that are likely to be pro-competitive, and recognize that condemning the implementation of governance systems - as a general matter-is likely to create false positives. The three-step analysis proposed above would better balance the costs of false positives and false negatives in light of the common use of governance systems to mitigate negative externalities and increase consumer welfare in platform communities.

While both private and public control of bad behavior on platforms have their place, private control through a platform will often be superior to public control. The platform can identify problems more easily, can correct these problems with greater agility, and is in a better position to minimize the unintended consequences of rules. Private governance of multi-sided platforms increases platform value to constituent communities and facilitates growth, development, and innovation. These benefits of private governance should have an important place in the analysis of anti-competitive charges against a platform's efforts to govern its community. 